Florida International University FIU Digital Commons

FIU Electronic Theses and Dissertations

University Graduate School

3-26-2015

\title{
Perceived Value of Fast-food Restaurant Franchises in the USA
}

Yisak Jang

yjang004@fiu.edu

DOI: $10.25148 /$ etd.FI15032187

Follow this and additional works at: https://digitalcommons.fiu.edu/etd

Part of the Food and Beverage Management Commons

\section{Recommended Citation}

Jang, Yisak, "Perceived Value of Fast-food Restaurant Franchises in the USA" (2015). FIU Electronic Theses and Dissertations. 1823.

https://digitalcommons.fiu.edu/etd/1823

This work is brought to you for free and open access by the University Graduate School at FIU Digital Commons. It has been accepted for inclusion in FIU Electronic Theses and Dissertations by an authorized administrator of FIU Digital Commons. For more information, please contact dcc@fiu.edu. 


\section{FLORIDA INTERNATIONAL UNIVERSITY}

Miami, Florida

PERCEIVED VALUE OF FAST-FOOD RESTAURANT FRANCHISES IN THE USA

A thesis submitted in partial fulfillment of the

requirements for the degree of

MASTER OF SCIENCE

in

HOSPITALITY MANAGEMENT

by

Yisak Jang

2015 


\section{To: Dean Mike Hampton}

School of Hospitality and Tourism Management

This thesis, written by Yisak Jang, and entitled Perceived Value of Fast-food Restaurant Franchises in the USA, having been approved in respect to style and intellectual content, is referred to you for judgment.

We have read this thesis and recommend that it be approved.

Miranda Kitterlin

Jinlin Zhao

Myongjee Yoo, Major Professor

Date of Defense: March 26, 2015

The thesis of Yisak Jang is approved.

Dean Mike Hampton School of Hospitality and Tourism Management

Dean Lakshmi N. Reddi University Graduate School

Florida International University, 2015 
C Copyright 2015 by Yisak Jang

All rights reserved. 


\section{DEDICATION}

I dedicate this thesis to my parents. Without their support, prayer, consideration, and most of all love, the completion of this work would not have been possible. 


\section{ACKNOWLEDGMENTS}

I would never have been able to complete my thesis without the guidance and support from my committee members. Words cannot express my deepest appreciation for my advisor, Dr. Michelle (Myongjee) Yoo, for her guidance, caring nature, and absolute patience. Not only did Dr. Yoo serve as my committee chair, but for the last two years of my graduate school life, Dr. Yoo has continuously been my mentor. Again, I would like to extend my sincere gratitude to her.

My committee members have also supported me with their valuable time and effort. To Dr. Zhao, I thank you for your gentle but firm direction and your trust in my abilities. To Dr. Kitterlin, your willingness to help students with warm words of encouragement have always impressed me. Thank you for your knowledgeable guidance and serving on my committee.

I wish to thank my parents and my older sister and brother. My family has always prayed for me and supported me with their best wishes. Finally, I would like to thank God. He gave me the opportunity to study in America and has always provided all I needed. Nothing can be compared to Your love for me. 


\begin{abstract}
OF THE THESIS
PERCEIVED VALUE OF FAST-FOOD RESTAURANT FRANCHISES IN THE USA
\end{abstract}

by

Yisak Jang

Florida International University, 2015

Miami, Florida

Professor Myongjee Yoo, Major Professor

The main research objective of this study was to find out whether perceived value significantly affects consumers' purchase intention. Additionally, this study examined if there are any significant differences in perceived value for different fast-food restaurant brands and attempted to identify which fast-food restaurant is perceived to be the industry leader.

A total number of six fast-food restaurants (McDonalds, Subway, Starbucks, Wendy's, Burger King, and Taco Bell) were selected. Findings showed that among the five perceived service value dimensions, Starbucks is the leader in terms of quality, emotional response, and reputation.

Multivariate analysis of variance (MANOVA) and multiple regression analysis were performed to test the study hypotheses. Results indicated that there were significant differences in perceived value for different fast-food restaurant brands. Besides, monetary and behavioral price significantly affects consumers' purchase intention. Findings are expected to help hospitality marketers to strategically manage their brands. 


\section{TABLE OF CONTENTS}

CHAPTER

PAGE

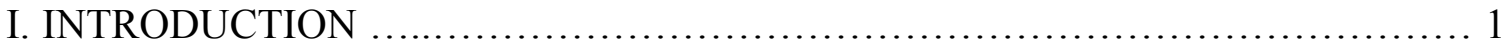

Problem Statement ....................................................... 3

Study Objectives and Justification ...................................... 3

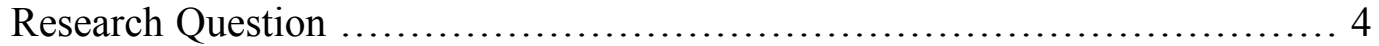

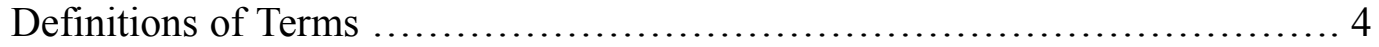

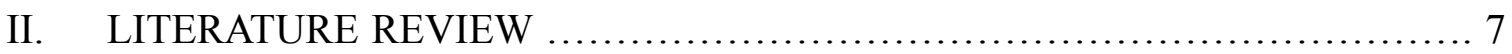

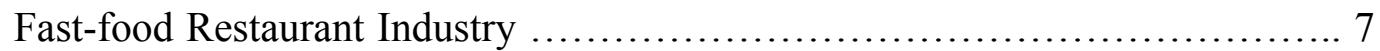

Fast-food Restaurants and Its Development......................... 7

Consumption in the Fast-food Restaurant Industry .................... 9

Franchise in the Fast-food Restaurant Industry ................... 10

Perceived Value ...................................................... 15

Concept of Perceived Value .................................... 15

Importance of Perceived Value .................................... 17

Measuring Perceived Value ............................................... 19

The multidimensional approach to perceived value ................. 19

Measurement Scale of Perceived Value of a Service ................. 22

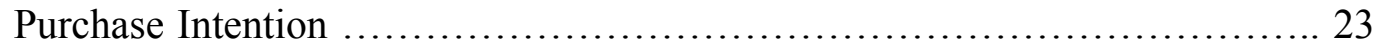

Influential factors of Purchase Intention .......................... 25

III. METHODOLOGY .............................................. 28

Research Hypotheses and Study Model. ............................... 28

Measurement Method and Scales ........................................ 30

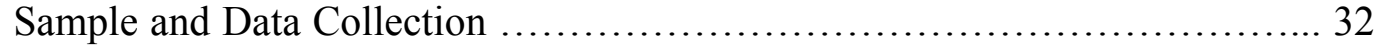

Data Analysis Method ............................................... 34

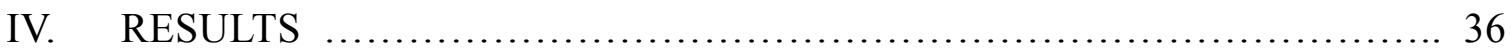

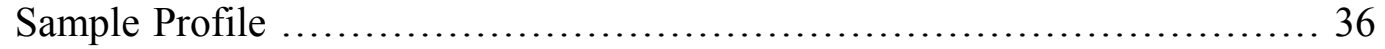

Comparison of Fast-food Restaurant Perceived Value ....................... 40

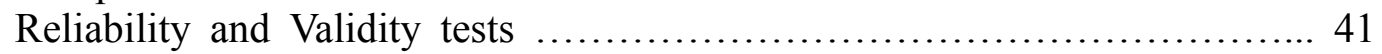

Testing of Hypotheses ............................................. 43

Multivariate Analysis of Variance (MANOVA) ................... 43

Factor Analysis ............................................... 51

Multiple Regression Analysis .................................. 55

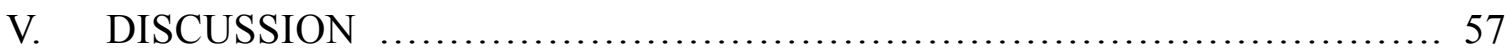

Discussion of Results ............................................. 57

Implications for Management........................................ 60

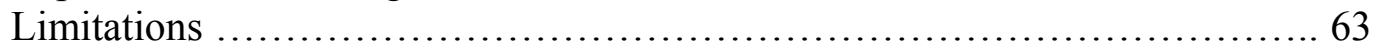

Recommendations for Future Research ............................... 64 
REFERENCES

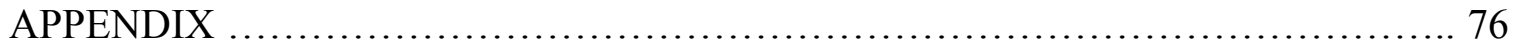




\section{LIST OF TABLES}

TABLE

PAGE

1. The Multidimensional Approach to Perceived Value ........................... 21

2. Petrick's Multidimensional Approach to Perceived Service Value ................ 22

3. Constructs and Items of the Questionnaire ................................. 31

4. Gender of Respondents .................................................. 36

5. Marital Status ......................................................... 37

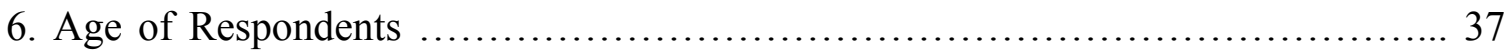

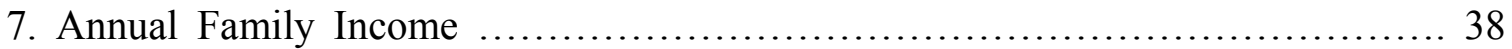

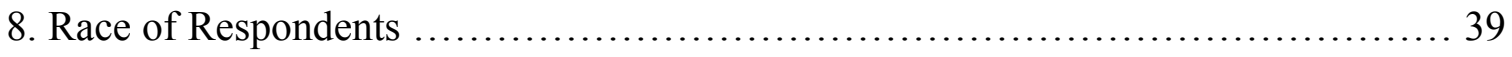

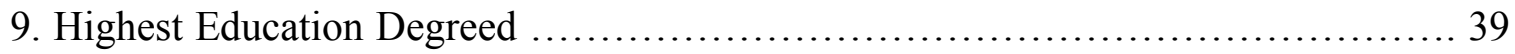

10. Mean Scores for Perceived Service Value Dimensions ........................ 40

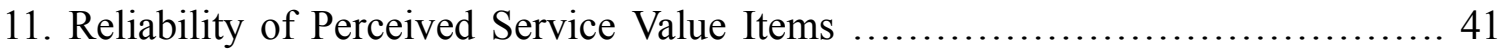

12. Reliability of Purchase Intention Items................................... 42

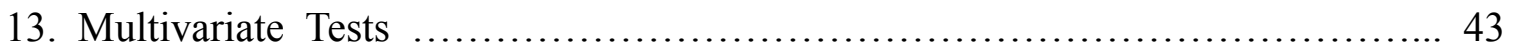

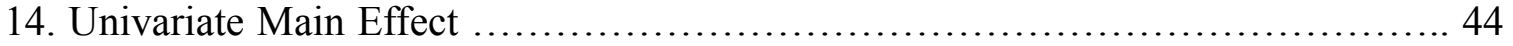

15. Post Hoc Tests (DV: Quality) ....................................... 45

16. Post Hoc Tests (DV: Emotional Response) ................................ 46

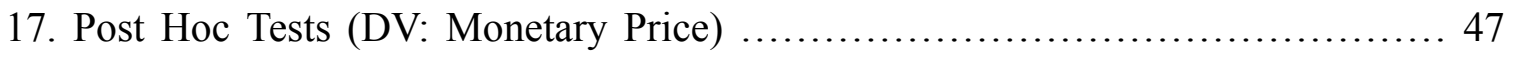

18. Post Hoc Tests (DV: Behavioral Price) .................................. 49

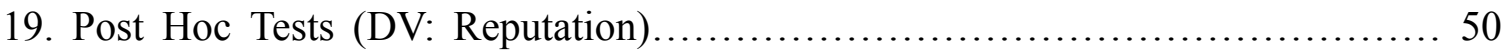

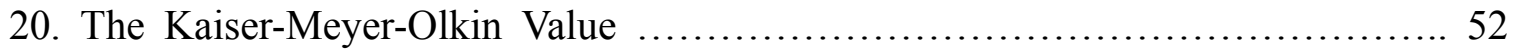

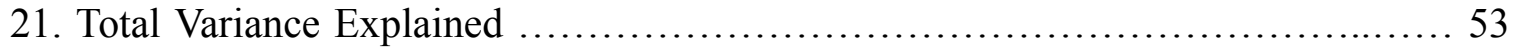


22. Factor Analysis: Rotated Component Matrix

23. Summary of Regression Analysis 55

24. Significance of Regression Coefficients 56 


\section{CHAPTER I}

\section{INTRODUCTION}

It is no secret; American people love fast food and it is not just them. The Golden Arches of McDonald's have spread all over the globe and new markets are one of the fastest growing areas in the industry (Franchise Help, 2015). The fast-food industry in the United States includes more than 232,000 restaurant locations and is generated by combined annual earnings of about 191 billion U.S. dollars in 2013. By 2018, this revenue is anticipated to exceed $\$ 210$ billion. The majority (77.3 percent) of this large market consists of on-premises restaurants and drive-through; the rest is comprised of off-premises dining (take out) and cafeterias and buffets (The Statistics Portal, 2014).

The fast-food restaurant industry, also known as Quick Service Restaurants (QSR), have been offering delicious food to customers. The first fast-food restaurants originated in the United States with A\&W in 1919 and White Castle in 1921 (Farrell, 2008). The modern style of fast food franchise started in the mid 1930s when Howard Johnson expanded his second unit and asked his friend to manage that unit. Well known large fast food restaurant chains such as McDonald's, Burger King, Kentucky Fried Chicken, and Sonic were established between the 1940s and 1950s. These changes affected society and "Fast-food" was subsequently added to the Merriam-Webster dictionary in 1951 (Franchise Help, 2015). The 1960s was particularly a period of growth in the fast-food restaurant and some major fast-food chains such as Subway and Wendy's were founded (Smith, 2006). 
In 1967, McDonald's opened its first restaurant outside the United States in Canada and Puerto Rico (McDonald's, 2014) and today American-founded fast-food franchise companies such as McDonald's, Burger King, and KFC are found in over 100 countries. Eating out is a common practice in the U.S. and the restaurant industry comprises a major part of the U.S. and the world economy. Approximately 83 percent of Americans visited fast-food restaurants at least once a week in 2013 (Statista, 2014). Its revenue has grown from $\$ 6$ billion in 1970 to $\$ 191$ billion in 2014, an 8.6\% annualized rate (Franchise Help, 2015).

However, the fast-food industry is experiencing its challenges, especially in the United States. Due to the increase in food cost, changing perceptions about health, and the recent economic recession, numerous fast-food restaurants have been struggling in business. In order to overcome this situation, the fast-food industry has been inventing new practices and providing new menus. Even though its opportunities exist in the "traditional" areas such as burgers and pizza, fast-food franchise restaurants also attempt to make more efforts related to healthier and unique products (Franchise Help, 2015).

Perceived value has grown into a popular subject to marketing managers and to researchers since it has been considered as one of the most effective measurement method of customer satisfaction and loyalty (Eggert \& Ulaga, 2002; Parasuraman \& Grewal, 2000). It is also regarded as one of the most influential indicators of purchase intention (Cronin, Brady \& Huit, 2000). Some research in the field of marketing emphasized that perceived service value is the best predictor of repurchase intention and repeat visitation (Cronin et al., 2000; Gale, 1994; Grewal, Monroe, \& Krishnan, 1998; Lee, 2005; Parasuraman, 1997). 
In order to have a competitive advantage in the service industry; it is important to find out the impact of perceived value. Most researchers agree that when customers have a positive perceptive value, they are motivated to make well-disposed decisions to a company (Kim \& Han, 2008; Yang \& Peterson, 2004; Woodruff, 1997). Maximizing a customer's perceived value is a successful strategy of a company in terms of long-term business success. Thus, a customer's perceived value can decide a company's future (Kim \& Han, 2008; Yang \& Peterson, 2004).

\section{Problem Statement}

For the last four decades, Americans' obsession with fast serving, cheap meals have made the fast-food restaurant a mainstay in their daily life. Fast-food restaurants have been constantly trying to increase competitive advantages as competition has become fierce. Perceived value plays an important role in creating competitive advantage as customers are only going to purchase the products or services they value (Doyle, 1998), thus, maximizing a customer's perceived value is a successful strategy of a company in terms of long-term business success (Kim \& Han, 2008; Yang \& Peterson, 2004). Although perceived value has gained significant research interest as a stable construct to predict buying behavior, there is limited empirical research in this subject related to fastfood restaurants. Therefore, it is essential to understand how perceived value affects a customers' purchase intention for a fast-food restaurant.

\section{Study Objectives and Justification}

The main research objective of this study was to find out whether perceived value significantly affects a consumers' purchase intention. Additionally, this study examined if there are any significant differences in perceived value for different fast-food 
restaurant brands and attempted to identify which fast-food restaurant is perceived to be the industry's leader. Overall the purpose of this study was to examine the impact of a customers' perceived value on fast-food restaurant purchase intention.

There are numerous studies on perceived value. However, the fast-food franchise restaurant industry is an area where not enough research has been done despite the importance of this topic. Therefore, this study is expected to contribute to the literature in the field of restaurant industry research.

Moreover, this study is expected to offer a better understanding of the relationships between perceived service value and a customer's purchase intention to a practical fast-food restaurant industry. This way, service providers can improve their perceived service value. The result of this study can guide businesses to achieve targeted improvements and develop strong and effective marketing strategies which may lead to customers' future intentions to purchase.

\section{Research Question}

The research questions addressed in this study is as following:

1. Which fast-food restaurant has the highest perceived value?

2. How does perceived value differ significantly among different fast-food restaurant brands?

3. How does perceived value have a significant impact on a customers' purchase intention for fast-food restaurants?

\section{Definitions of Terms}

Throughout the current study, the following terms are used for the purpose of conceptualizing perceived value and defining purchase intention. 
Affective dimension: the feeling or sentiments made by products and services (Sanchez, J.,

Callarisa L., Rodriguez M.R., \& Moliner A.M., 2006).

Behavioral price: The price (non-monetary) of obtaining a service such as time and effort used to look for the service (Zeithaml, 1988).

Emotional response: A descriptive assessment about the satisfaction and pleasure that a product or service gives the consumer (Sweeney, Soutar, \& Johnson, 1998).

Fast-food restaurant: The restaurant that sells fast prepared foods (Ware \& Rudnick. 1991).

Franchise: A franchise is a right that signifies the relationship between the franchisor and the franchisee including the use of trademarks, business systems, fees, support, and control (Coelho, 2006).

Franchising: A franchisor grants a franchisee the right and license to sell a product or service, or both, by using the trademark and the operation system that are invented by the franchisor (Khan, 2005).

Monetary price: The price of a service as encoded by the consumer (Jacoby \& Olson, 1977)

Perceived value: "the consumer's overall assessment of the utility of a product (or service) based on perceptions of what is received and what is given" (Zeithaml, 1988, p. 14).

Purchase intention: The transaction behavior that consumers tend to perform after assessing a product; or the purchase possibility based on the consumer's response to a product (Dodds, W.B., Monroe, K.B., \& Grewal, D., 1991; Schiffman \& Kanuk, 2000; Spears \& Singh, 2004). 
Quality: A purchase assessment regarding a product of the service's overall superiority or excellence (Zeithaml, 1988).

Quick-service restaurant. A quick-service restaurant is developed to get customers in, out, and on their way in less than five minutes (Robinson, Abbott, \& Shoemaker, 2005). The quick-service industry is usually called 'fast food' (Richardson, 2001).

Reputation. The prestige of status of a product or service received by consumer on the basis of the image of the supplier (Dodds et al., 1991). 


\section{CHAPTER II \\ LITERATURE REVIEW}

\section{Introduction}

The objective of this chapter is to better understand the concepts underlying the fast-food industry, perceived value and purchase intention. The literature review is separated into four different sections. The first section reviews fast-food restaurant industry, its development and consumption, and its franchising system. The second section describes what perceived value is and why it is important. The third section presents the measurement scale of perceived value of a service. Finally, the fourth section describes the definition and the influential factors of purchase intentions.

\section{Fast-food Restaurant Industry}

\section{Fast-food Restaurants and Its Development}

A fast-food restaurant is defined as the restaurant that sells fast prepared foods. These types of restaurants generally use a franchising system. They usually have limited and low-priced menu and the food can be taken out in disposable containers. The minimum hiring qualifications is required and employees need not to be thoroughly trained (Ware \& Rudnick, 1991).

Automating concept is the key component of contemporary fast-food restaurants. The automation in fast-food restaurant operation indicates diminution in menu selection and limited customer service. Due to the application of self-service, customers substitute for serving and tidying up. Furthermore, fast-food restaurants can develop specialized and efficient kitchens because they provide simple and limited menus (Powers, 1992). 
The fast-food restaurant industry has grown and expanded at an enormous pace over the last century. Schlosser (2012) states that many people regard fast-food restaurants as a concept of modern technology. However, fast-food restaurants existed during the Roman Empire, and French-speaking West African countries, as well as in a variety of cultures in the East and Middle Asian countries (Mihrete, 2012).

According to Jakle (1999), the first coin-operated fast-food restaurant in U.S. was opened in New York City in 1912. Afterwards, Automat, a coin or bill operated food vending machine was opened by Horn and Hardart. It expanded and increased throughout the United States from 1920s to the 1930s. The first fast-food chain, White Castle, was founded in 1921, in Topeka, Kansas. After World War II, the development of automotive industry caused the growth of many drive-in fast-food restaurants (Levenstein, 2003). Well known large fast food restaurant chains such as Kentucky Fried Chicken, McDonald's, Burger King, and Sonic were established between the 1940s and 1950s. The 1960s was particularly a period of growth in the fast-food restaurant and some major fastfood chains such as Subway and Wendy's were founded (Smith, 2006).

Fast-food restaurants in U.S. were established and developed based on the principle of standardization. All restaurants had the same outward appearance and interior design, provided the same menus, and had the same operating systems. In the 1990s, many fast food restaurant franchises started to expand throughout the world by franchising. Fast food is usually considered as an American product outside of the United States. Thus, several countries took time to absorb the novel style of these fast food restaurants (Smith, 2006). 


\section{Consumption in the Fast-food Restaurant Industry}

There have been progressive life style changes in the U.S., as Americans spend more money on fast food than they do on other products such as new cars, personal computers, higher education, videos, movies, newspapers, books, magazines, and recorded music (Schlosser, 1998). In 2013, the United States consumed \$191 billion on fast food and captured about 64.8 percent of the fast-food revenues from the top ten fast food consumption countries around the world. An average American spends \$1,200 per year on fast food (DailyMail, 2014). Eating out is a common practice in the U.S. and the restaurant industry comprises a major part of the United States and the world economy. Approximately 83 percent of Americans visited fast-food restaurants at least once a week in 2013. When eating out, the majority of U.S. consumers used fast-food or fast casual restaurants for lunch in 2013 (Statista, 2014). Overall, the Fast-food industry accounts for roughly 25 percent of the total restaurant industry sales and number of stores (National Restaurant Association, 2006).

In spite of the explosive growth of the fast food industry, fast-food restaurants relatively have low-profit margins ranging from an average of only four to seven percent (Nessel, 2010). The slim-profit margin of the fast-food restaurant industry originated in the insistent wholesale-food price inflation. For instance, the wholesale-food price increased by 7.6 percent in 2007 and 8.5 percent in 2008 (Wikinvest, 2012).

To make matters worse, nowadays the fast-food restaurant industry has gone through a noticeable slowdown in growth due to the most recent recession until 2010 and change in consumer's tastes (Anthony, 2008; Samadi, 2010). The sales of the fast-food restaurant industry in U.S. decreased by 4.7 percent in 2009 (Statista, 2014). Due to the 
saturation and maturity of a fast-food restaurant and the global economic recession; fastfood restaurants have recently experienced keen competition.

With low-profit margins and intense competition, the success of a fast-food restaurant is determined by its capability to maintain patrons by improving customer value or enhancing service provision. Moreover, as customers are no longer loyal to a particular fast-food restaurant brand, fast food restaurants are constantly struggling to increase market share (Reichheld \& Sasser, 1990; Lovelock \& Wright, 2002). Kotelikov (2008) stated that a two percent rise in customer retention has the same influence on profits as cutting costs by 10 percent. Further, a five percent decline in customer defection rate can raise profits by 25 to 125 percent.

\section{Franchise in the Fast-food Restaurant Industry}

Franchising is considered as a well-known and popular way of business growth and expansion for U.S. multinational companies (Duckett, 2008; Kapil, 2009). Utilization of franchise system for doing business started in the U.S. in the early 1900's (Alon \& McKee, 1999; Baena, 2009). The U.S has been regarded as a pioneer in the franchising industry and remains the global leader in restaurant franchising (Khan, 2005).

A franchise refers to a right that signifies the relationship between the franchisor and the franchisee including the use of trademarks, business systems, fees, support, and control (Coelho, 2006). The US Department of Commerce defined franchising as, “A method of doing business by which a franchisee is granted the right to engage in offering, selling, or distributing goods or services under a marketing format which is designed by the franchisor. The franchisor permits the franchisee to use the franchisor's trademark, name, and advertising" (Kostecka, 1987, p. 2). Khan (2005) defined franchising as a 
franchisor grants a franchisee the right and license to sell a product or service, or both, by using the trademark and the operation system that was invented by the franchisor.

A franchisor uses a franchising system in order to reduce entrepreneurial risk because a developed business concept, management, and marketing know-how apply to new markets (Baena, 2009). Basically, franchising strategies are used by franchisors to penetrate markets, expand their enterprise, and make sure of a competitive advantage (Rahatullah \& Raeside, 2009).

Fast-food franchises depend on consistency and uniformity in terms of operation systems and brand image across all of their franchise units in order to deliver a sense of credibility and reliability to their customers. Customers are able to build trust towards a company through credibility and reliability, and further trust increases customer loyalty, a strong source of competitive advantage for businesses. When a person is asked to make a choice of different restaurants to eat at, it is much better and easier for them to adhere to what they know, rather than to take the risk for the unknown. Because of the importance of consistency and uniformity, most fast-food franchise set standards to unify their variety of units with a set of common criteria and regulations. Franchisors usually depend on field representatives to verify whether franchisees follow the parent company's standards or not. The more units a fast-food franchisor has, the more difficult it is for the franchisor to control these standards (Hornsby, 2011). 
There are numerous fast-food franchises in the U.S.A due to its popularity. From beverages to simple meals, the scope and types of fast-food franchises differ significantly. This study selected the top six fast food restaurants in the order of the 2013 U. S. system wide sales according to the Top 50 Brands in Quick Service and Fast Casual (Quick Service Restaurant Magazine, 2014).

McDonald's. McDonald's is one of the most well known brand names in the world. There is almost no person in the modernized states who has not entered McDonald's because it is the largest and the most renowned fast-food franchise restaurant around the world (Panczel, 2010). According to McDonalds.com, the fist McDonald's was opened in 1940 in San Bernardino, California. They are currently found in 119 countries across more than 36,000 outlets (McDonalds, 2014).

Most McDonald's restaurants have both counter service style and drive-through service style, with usually indoor and sometimes outdoor tables. Drive-Thru, Auto-Mac, Pay and Drive, or "McDrive" as it is known in many countries, often has separate stations for placing, paying for, and picking up orders, though the latter two steps are frequently combined; it was first introduced in Arizona in 1975, following the lead of other fast-food chains. The first such restaurant in Britain opened at Fallowfield, Manchester in 1986 (The Caterer, 2011).

Subway. Subway is an American fast-food restaurant franchise that primarily offers submarine sandwiches (subs) and salads. It is owned and operated by the Doctor's Associates, Inc. Subway is one of the fastest growing franchises in the world and there are 43,035 outlets in 108 countries and territories as of November 15, 2014. It is the largest single-brand restaurant chain and restaurant operator globally (Subway, 2014). 
Since 2007, Subway has consistently ranked in Entrepreneur magazine's Top 500 Franchises list. It ranked \#3 in 2014. It also ranked \#1 on the "Fastest Growing Franchise" lists (Entrepreneur magazine, 2014). At the end of 2010, Subway became the largest fast food chain worldwide, with 33,749 restaurants - 1,012 more than McDonald's (Jargon, 2011).

Starbucks Coffee. Starbucks Coffee is one of the most well known American global coffee chain company based in Seattle, Washington. Starbucks is the largest coffeehouse company in the world ahead of rival Costa Coffee based in United Kingdom. There are 21,160 outlets in 63 countries, including 12,067 in the U.S., 1,570 in China, 1,451 in Canada, 1,070 in Japan and 793 in the U. K (Starbucks, 2014).

Starbucks first started business in 1971 as a Seattle coffee bean roaster and retailer. Starbucks became famous for its high-quality specialty coffee and began expanding at a rapid pace (Bussing-Burks, 2009). Not only was the expansion rapid in the U.S., but there was also a rapid global expansion beginning in Tokyo in 1996 and continued into large markets around the world in areas such as Australia, Canada, Germany, Japan, Russia and many others; each market had adaptations that applied to their specific market culture (Bussing-Burks, 2009).

The explosive growth and expansion did not result solely from their high-quality coffee or their various espresso drink combinations; but it is attributed to the "Starbucks experience." Starbucks became famous for the high value they give to their customers and their effort to their values. The "Starbucks experience" began to make the Starbucks culture (Kauffman, 2013). Schultz and Yang (1997) indicated that "at Starbucks, our product is not just great coffee but also what we call the 'Starbucks experience:' an 
inviting, enriching environment in our stores that is comfortable and accessible, yet also stylish and elegant" (p. 251).

Wendy's. Wendy's is an international fast-food restaurant franchise established by Dave Thomas in 1969, in Columbus, Ohio, United States. Wendy's is the third largest fast-food hamburger company in the world. Wendy's has more than 6,500 franchises and company store in the United States and 29 other countries (Wendy's, 2015).

Wendy's sells hamburgers, chicken sandwiches, french-fries, and beverages. Wendy's is distinct from McDonald's or Burger King because they do not have a signature sandwich like the Big Mac or the Whopper. Instead, Wendy's regards their patty as their signature item because they use a fresh ground beef patties rather than frozen patties (Wikipedia, 2015).

Burger King. Burger King is an international franchise of hamburger fast-food restaurants headquartered in unincorporated Miami-Dade County, Florida, United States. The company started a business in Jacksonville, Florida in 1953 under the name of InstaBurger King. After Insta-Burger King had financial difficulties in 1954, its two Miamibased franchisees, David Edgerton and James McLamore, acquired the company and changed its name to Burger King (Carlino, 1996; Smith, 2006).

When Insta-Burger King first began in Jacksonville in 1953, its menu was comprised of basic hamburgers, french fries and soft drink. After being given its current name in 1954, Burger King started expanding its menus by adding the Whopper sandwich in 1957. It was created to differentiate Burger King from other burger restaurants at that time. Eventually, The Whopper became the symbol of Burger King (Carlino, 1996). Actually, Burger King followed McDonalds's system for a long time 
(Ries \& Trout, 2001). They first opened an outlet in Europe in Madrid, Spain, in 1975. In China, the first Burger King started business in 2005. Currently, Burger King is founded in 61 countries with more than 12,000 outlets and the total number of its customer is more than 15 million (Burger King, 2014).

Taco Bell. Taco Bell is the American leading Mexican-inspired fast-food restaurant franchise based in Irvine, California. It is branded under Yum! Brands, Inc. and they sell various Texan and Mexican foods such as: tacos, burritos, quesadillas, nachos, and so on. Taco Bell was established by Glen Bell and he first opened a hot dog stand named Bell's Drive-In in San Bernardino, California in 1946 (Taco Bell, 2015). He founded the first Taco Bell in Downey, California in 1962. Currently, Taco Bell has more than 6,500 restaurants across U.S. that serves more than 36 million customers every week (Taco Bell, 2015).

Taco Bell built the first Taco Bell Express in San Francisco in 1991. This concept is a reduced size restaurant that sells limited menu and its main menu price was under $\$ 1$. It was located mainly inside convenience stores, airports, shopping malls, and truck stops (Toledo Blade, 1991). In 1995, Taco Bell started co-branding with KFC in Clayton, North Carolina. They continued its co-branding strategy with Pizza Hut and Long John Silver's as well (Chron, 2012).

\section{Perceived Value}

\section{Concept of Perceived Value}

Perceived value has been defined in diverse ways as the value concept is multifaceted and complicating with numerous interpretations, biases, and emphases (Huber, Hermann, \& Morgan, 2001). The value of products can be considered as the tradeoff 
between what the product can provide to the customer and what the customer has to pay to buy the products (Sweeney \& Soutar, 2001; Zeithaml, 1988). In this context, perceived value has been defined as, "the consumer's overall assessment of the utility of a product (or service) based on perceptions of what is received and what is given" (Zeithaml, 1988, p. 14). The equity theory addresses that a customer assesses right, reasonable, or deserved values for the perceived cost of the offering, including pecuniary payments and nonpecuniary sacrifices, such as time consumption, energy consumption, and stress suffered by a customer (Bolton \& Lemon, 1999; Yang \& Peterson, 2004). Even though there are minor disagreements on the definition of perceived value, researchers generally present it as an individuals' overall assessment of both monetary and non-monetary considerations about the product or service, on the basis of a tradeoff between the relative benefits and the sacrifices required to obtain such benefits (Oh, 2000; Yang and Peterson, 2004; Zeithaml, 1988).

A common ground of a variety of researchers' definitions about perceived value is that the relationships among perceived quality and product value for a customer has relevance to his or her knowledge of a product. Besides, value for a customer has relevance to the perception of a customer and cannot be caused by and an organization. Research also agrees that perceived value is a multidimensional concept (Gallarza \& Saura, 2006; Sanchez, Callarisa, Rodriguez, \& Moliner, 2006; Cronin, Brady, \& Huit, 2000).

Parasuraman and Grewal (2000) conceptualized perceived value as a decisive construct for building long-lasting relationships with customers. The concept of perceived value is longstanding and endemic to a consumer's behavior (Gallarza and 
Saura, 2006). However, after 1990, this concept was retouched because numerous companies were asked to reorient their strategic plan towards higher consumer value delivery (Band, 1991; Day, 1990; Gale, 1994; Naumann, 1995). Since then, consumer perceived value has been recognized as one of the most important management factors for attracting consumers together with quality, consumer satisfaction and loyalty (Cengiz \& Kirkbir, 2007).

Generally, perceived value has been researched from a rational perspective. However, researchers are paying more attention to the emotional factor as well. Products and services also possess emblematic meanings beyond the tangible feature, such as perceived quality or perceived price (Havlena \& Holbrook, 1986). When it comes to researching perceived value, it is necessary to consider not only a cognitive factor, but also an affective factor based on that point of view (Sanchez et al. 2006). Researchers (Cronin et al., 2000; Parasuraman \& Grewal, 2000) found that service quality is an important factor of perceived value.

\section{Importance of Perceived Value}

Perceived value has grown into a popular subject to marketing managers and to researchers since it has been considered as one of the most effective measurement method of customer satisfaction and loyalty (Eggert \& Ulaga, 2002; Parasuraman \& Grewal, 2000). It is also regarded as one of the most influential indicators of purchase intention (Cronin, Brady \& Huit, 2000). Maximizing a customer's perceived value is a successful strategy of a company in terms of long-term business success (Kim \& Han, 2008; Yang \& Peterson, 2004). Most researchers agree that when customers have a 
positive perceptive value, they are motivated to make well-disposed decisions to a company (Kim \& Han, 2008; Yang \& Peterson, 2004; Woodruff, 1997).

Perceived value is one of the most influential factors to obtain competiveness and it is regarded as a crucial predictor of customer satisfaction and loyalty (McDougall \& Levesque, 2000; Cronin et al., 2000). Many researchers in different fields of study conceptualized a model of perceived value as the connecting link between quality, sacrifices, and satisfaction. The findings of these studies show that value significantly effects satisfaction. Representative study findings indicate (Cronin, 2000; Ulaga, 2001) that perceived value has a positive relationship with customer satisfaction. In general, higher perceived value influences higher degree of customer satisfaction and the relationship is relatively robust. Gallarza and Saura (2006) also researched the relationship among perceived value, satisfaction and loyalty in the hospitality industry. The findings of their study pointed out that perceived value is considerably concerned with a customers' satisfaction.

Perceived value plays an important role in creating a competitive advantage because customers are only going to purchase product or services they value (Doyle, 1998). Olshavsky (1985) indicates that one of the effective ways to understand the perceived value of a brand is to find out a reason for purchase. The perceived value of a product is a predictor of a customer's intention to purchase or not to purchase (Groth, 2001; Monroe, 1990; Zeithaml, 1988).

Schiffman and Kanuk (1994) indicates that a customers' purchase behavior is comprised of a variety of other behaviors such as: seeking, buying, using, and assessing products or services and ideas meeting their expectations. In face-to-face shops, 
information from goods and service quality of salespersons plays an influence on a customer's purchase intention and behavior. The characteristics of internet shopping will also have an effect on internet customers' and their purchasing intentions and behavior (Ranganathan \& Ganapathy, 2002; Wakefield, Stocks, \& Wilder, 2004). The decision process of purchasing for a customer starts when their needs are satisfied by acquiring a certain product or service (Kim, Ma, \& Kim, 2006).

\section{Measuring Perceived Value}

\section{The multidimensional approach to perceived value}

Perceived value was generally measured by conducting a self-reported and onedimensional measurement asking customers to evaluate the value they received for their purchase in the past (Gale, 1994). However, the unidimentional measure assumes that customers have one shared meaning of value. Zeithaml (1988) insists, "Quality and value are not well differentiated from each other and from similar constructs such as perceived worth and utility (p. 471)." Therefore, Woodruff \& Gardial (1996) claimed that the onedimensional measure of perceived value has a lack of validity. Additionally, the onedimensional measure indicates how well one is evaluated for value, but do not provide particular direction on how to ameliorate and enhance value (Petrick, 2002).

Perceived value has been principally evaluated with a single-item or multi-item scales that address the functional value (Park, Jaworski, \& Maclnnis, 1986; Sheth, Newman, \& Gross, 1991), financial value (Anderson and Srinivasan, 2003; Dodds et al., 1991; Ramanathan \& Ramanathan, 2011; Pura, 2005), and psychological value (Dodds et al., 1991; Sheth et al., 1991; Zeithaml, 1988). The composition of perceived value has been extended to include mixed dimensions, for example; intrinsic and extrinsic value by 
Babin, Darden, \& Griffin (1994) and Novak, Donna, \& Duhachek (2003); the six-facet value of "PERVAL" by Sweeney and Soutar (2001); and the five consumption dimensions by Sheth et al., (1991).

Sweeney and Soutar (2001) developed a 19-sitem measure, PERVAL, that can evaluate a customers' perceive value of consumer durable goods at a brand level. The measure was made for use in a retail purchase condition to find out what consumption values generate purchase behavior.

Table 1 summarizes the authors who have chosen the multidimensional approach and the dimensions of the construct for perceived value. All the researchers have the two common fundamental dimensions of perceived value: functional and affective (Anderson \& Narus, 1990; Gassenheimer, Houston, \& Davis, 1998; Lapierre, 2000; Sweeney \& Soutar, 2001; Palmer \& Ponsonby, 2002). The functional dimension indicates the reasonable and economic assessments generated by individuals. The quality and price of the product and of the service belongs to this dimension. The affective dimension refers to the feeling or sentiments made by the products and services. There is a growing agreement to separate it into an emotional dimension (relating to internal feelings and sentiments) and a social dimension (relating to the social impact on status and reputation). Even though these researches show objective evidence of the existence of the functional and affective dimensions of perceived value, there is a limited point that none of them find out the overall perceived value of a purchase. However, any attempt to make a scale of measurement of the overall perceived value of a purchase, or to establish its dimensions, must apply a structure that indicates functional and affective dimensions (Sanchez et al., 2006). 
Moreover, the fact that a consumer is "satisfied" with a product or service does not necessarily imply the product or service is a good value. It is perfectly possible that a consumer who is really content with a product or service may regard it as a poor value if the price for acquiring is perceived to be too high. On the other hand, a slightly satisfied consumer may find a service to have good value, if he or she thinks it offered a good utility for the cost paid (Petrick, 2002).

Table 1

The Multidimensional Approach to Perceived Value

\begin{tabular}{|c|c|}
\hline Author & Dimensions \\
\hline Sheth et al. $(1991 \mathrm{a}, \mathrm{b})$ & $\begin{array}{ll}\text { - } & \text { Social value } \\
\text { - } & \text { Emotional value } \\
\text { - } & \text { Functional value } \\
\text { - } & \text { Epistemic value } \\
\text { - } & \text { Conditional value }\end{array}$ \\
\hline Groth $(1995 a, b)$ & $\begin{array}{l}\text { - Cognitive: perceived utility } \\
\text { - } \quad \text { Psychological } \\
\text { - } \quad \text { Internal } \\
\text { External }\end{array}$ \\
\hline Gronroos (1997) & $\begin{array}{ll}\text { - } & \text { Cognitive } \\
\text { - } & \text { Emotional (psychological) }\end{array}$ \\
\hline $\begin{array}{l}\text { de Ruyter, Wetzels, Lemmink, and Mattson } \\
\text { (1997) }\end{array}$ & $\begin{array}{l}\text { - Emotional dimension or intrinsic value } \\
\text { - } \quad \text { Functional dimension or extrinsic value } \\
\text { - Logical dimension }\end{array}$ \\
\hline Sweeney, Soutar, and Johnson (1999) & $\begin{array}{ll}\text { - } & \text { Social value (acceptability) } \\
\text { - } & \text { Emotional value } \\
\text { - } & \text { Functional value (price/value for money) } \\
\text { - } & \text { Functional value (performance/quality) } \\
& \text { Functional value (versatility) }\end{array}$ \\
\hline Sweeney and Soutar (2001) & $\begin{array}{ll}\text { - } & \text { Functional dimension (economic and } \\
& \text { quality) } \\
\text { - } & \text { Social dimension } \\
\text { - } & \text { Emotional dimension }\end{array}$ \\
\hline
\end{tabular}

Note. Source: Reprinted from "Perceived Value of the Purchase of a Tourism Product", Sanchez et al., 2006, Tourism management, 27(3), p. 396. 


\section{Measurement Scale of Perceived Value of a Service}

Research evolved and the multi-dimensional measurement scales for the perceived value of tangible products have become frequently utilized (Kantamneni \& Coulson, 1996; Sweeney, Soutar \& Johnson, 1999). However, a multi-dimensional scale for measuring the perceived value of intangible services did not exist. Former research (Jayanti \& Ghosh, 1996; Petrick, 1999) found that scales established for measuring a perceived value of product are difficult to utilize when measuring perceived value of a service. They went on to say that the underlying dimensions in a service are different from those of a product. Lovelock (1983) insisted that services are different from products, in that they are intangible, variable and inseparable. Thus, there was a need for developing an additional scale that took account for these properties in measuring the perceived value of a service.

Table 2

Petrick's Multidimensional Approach to Perceived Service Value

\begin{tabular}{|c|c|}
\hline Author & Dimensions \\
\hline Petrick (2002) & $\begin{array}{ll}\text { - } & \text { Quality } \\
\text { - } & \text { Emotional Response } \\
\text { - } & \text { Monetary Price } \\
\text { - } & \text { Behavioral Price } \\
\text { - } & \text { Behavioral Reputation }\end{array}$ \\
\hline
\end{tabular}

For these reasons, Petrick (2002) established a five dimension measurement scale for perceived value of a service that was used in this study (see Table 2). The five 
dimensions were: interrelated and composed of quality, behavioral price, monetary price, response, and reputation. Lee (2005) applied Petrick's multi-dimensional scale to his study to measure perceived value of a service in a festival situation. The results of the study found that perceived value of a service plays an important role in the future behavioral decision of visitors. The study also revealed that there was a robust correlation between perceived value of a service and behavioral intention. As a result, the study identified the most influential attributes to give guidance to companies and managers in the field of service on creating marketing strategies.

\section{Purchase Intention}

The best predictor for anticipating actual behavior is the intention of a person to execute the behavior (Fishbein \& Ajzen, 1975). Purchase intention has served as a dependent measure in numerous researches in defect of actual behavioral data (Manski, 1990). Purchase intention refers to one's personal forecast regarding the possibility of future behavior; or the transaction behavior that consumers tend to perform after assessing a product; or the purchase possibility based on the consumer's response to a product (Dodds et al., 1991; Manski, 1990; Schiffman \& Kanuk, 2000; Spears \& Singh, 2004).

Even though purchase intention plays an important role in anticipating actual behavior, the forecast does not correspond with reality. For instance, Morrison (1979) found out that among the people who express their intention to purchase a car, only 53 percent of people actually did it. Tauber (1975) argued that even if the forecasts of actual behavior by utilizing purchase intention may be overrated, it was found that purchase intention has correlation with actual behavior in terms of new products. Moreover, 
Fishbein and Ajzen (1980) insisted that intention always serve as forecasting behavior as long as preferences were not altered at the moment of the behavior to be executed and intention measure had relevance to the behavior.

Purchase intention has become an important concept and has been the focus of numerous of researches, particularly in the field of management and marketing (Chandon, Morwitz, \& Reinartz, 2005; Dholakia \& Vicki, 2002; Mittal \& Wagner, 2001; Morwitz, 2001; Morwitz \& Gavan, 2004). Also, purchase intention has gained significant research interest as a stable construct to predict buying behavior (Anderson \& Srinivasan, 2003; Armstrong \& Kotler, 2003; Chen \& Dubinsky, 2003; Cronin et al., 2000; Oh \& Xu, 2003; Pura, 2005).

In the context of marketing, purchase intention refers to a combination of a consumer's interest in and the probability of purchasing a product or service on the basis of promotional messages admitted (Schiffman \& Kanuk, 2000). Purchase intention is regarded as an important factor since it helps to accomplish an understanding of consumer behavior and functions as a predictor of purchase behavior. Morwitz and Schmittlein (1992) consider purchase intention as the most valuable item of a marketer's prediction of purchase behavior within the marketing research field. Kim, Kim \& Johnson (2010) insisted that predicting the future behavior of consumers is becoming increasingly significant. Actually, purchase intention is the key indicator utilized in forecasting consumer behavior (Armstrong \& Kotler, 2003).

Additionally forecasting a consumer's future behavior, particularly their purchase behavior, is regarded as an important aspect of anticipating and planning. For this reason, when a company is trying to draw or keep customers, understanding their 
purchase intention serves as a major factor (Thang, 2008). Numerous studies indicated that the majority of companies depend on a consumer's purchase intention to make a decision to adopt new products or repeat exiting ones (Cornwell \& Coote, 2005; Hellier, Geursen, Carr, \& Rickard, 2003; Ngoc, 2009). For example, Chandon, Morwitz, and Reinartz (2005) carried out an empirical research to find out the relation between the purchase intention of consumers and the sales of cars, personal computers, and groceries. They insisted that the result of the research indicated that there is a positive relationship between a consumer's purchase intention and the sale of cars, personal computers, and groceries. Furthermore, in the field of sports, Super Bowl sponsors decide how much money they need to make an investment in advertisement and sponsorship on the basis of a consumer's purchase intention. The results suggested that a consumer's purchase intention have great influences on advertisement and sponsorship (O’Reilly, Lyberger, McCarthy, Séguin, \& Nadeau, 2008).

\section{Influential factors of Purchase Intention}

Many researchers found out that purchase intention is highly related to preference towards a brand or a product (Kim, Kim \& Johnson, 2010; Kim \& Ko, 2010a; Kim \& lee, 2009, Lloyd \& Luk, 2010). It is assumed that the cognitive processes related with purchase decision occurs before the actual purchase. For this reason, marketers have to be aware of how to affect prospective customers in their pre-purchase stage.

In the service field, perceptions and perceived value of a service affects purchase intention and how positively or negatively a person talks to others about their service experience (Petrick, 2002). Perceived value plays an important role in creating competitive advantage because customers are only going to purchase products or services 
they value (Doyle, 1998). Therefore, the perceived value of a product or service is a predictor of a customer's intention to purchase or not to purchase (Groth, 2001; Monroe, 1990; Zeithaml, 1988).

Numerous empirical research supports the relationship between perceived quality and perceived value (Bolton \& Drew, 1991; Zeithaml, 1988). Such study has shown that perceived quality serves as the principal indicator of perceived value, which ultimately leads to purchase intention. Bolton and Drew (1991) insisted that partial future intentions were decided by perceived service value. Some research results indicated that perceived service value have a stronger power to predict purchase intention than perceived service quality and satisfaction (Cronin et al., 2000; Lee, 2005; Oh, 2000).

For example, Lee (2005) conducted a research in a festival setting to examine the relationships among three performance indicators (perceived service quality, perceived service value, and satisfaction) to measure which had the best predictive power on a visitor's behavioral intention. According to her study, perceived service value had a stronger relationship with the visitor's behavioral intention compared to perceived service quality and satisfaction. This indicated that perceived service value is the best predictor of behavioral intention.

\section{Summary}

This chapter reviewed several important concepts in the study. A fast-food restaurant is defined as the restaurant that sells fast prepared foods. These types of restaurants usually adopt a franchising system(Ware \& Rudnick, 1991). Perceived value is defined as "the consumer's overall assessment of the utility of a product (or service) based on perceptions of what is received and what is given" (Zeithaml, 1988, p. 14). Also, 
it is a predictor of a customer's intention to purchase or not to purchase (Zeithaml, 1988;

Monroe, 1990 ; Groth, 2001 ). Purchase intention is an individual's plan to purchase products (Spears \& Singh, 2004). 


\section{CHAPTER III}

\section{METHODOLOGY}

\section{Introduction}

This chapter focuses on the research methods used to test the study hypotheses. The study hypotheses, the measurement method and scales, sample and data collection methods, and the data analysis process are discussed in the following section.

\section{Research Hypotheses and Study Model}

The findings of the literature review emphasizes the importance of perceived value as a competitive advantage for businesses, as it plays a powerful role in affecting the customer's satisfaction, loyalty, and purchase intention (Cronin, Brady \& Huit, 2000; Parasuraman \& Grewal, 2000). Companies thrive to maximize the perceived value of their product or service for long-term business success (Kim \& Han, 2008; Yang \& Peterson, 2004). Additionally, the findings of the literature review suggest that there is a positive relationship between perceived value and purchase intention (Doyle, 1998; Groth, 2001; Zeithaml, 1988).

Tsang and Qu (2000) showed that the perceptions of tourists and hotel managers in the hospitality industry differ because their expectations of quality of service are different. Moreover, Xie and Chen (2014) found out hotel loyalty programs differ significantly in perceived program value based on different hotel brands. Thus, this evidence indicates that differences in perceived service value are likely to occur across fast-food restaurant brands and the first hypothesis was derived as the following: 
H1: Perceived value differ significantly among different fast-food restaurants brands.

A number of studies argued that the perceived value of a product is a predictor of a consumer's intention to purchase. A consumer is more likely to purchase a product in which he/she finds value in (Groth, 2001; Monroe, 1990; Zeithaml, 1988). Likewise, it was found that there is a direct correlation between perceived service value and behavioral intention. Perceived value played an important role on a visitor's future decision making behavior for a festival as well (Lee, 2005). Thus, it is expected that perceived value will also impact fast-food franchise restaurant purchase intention and the second study hypothesis was derived as following:

H2: Perceived value has a positive influence on customers' purchase intention for fast-food restaurants.

Overall, this study utilized Petrick's (2002) five dimension scale to measure perceived service value, which is composed of: quality, emotional response, monetary price, behavioral price, and reputation. The following study model has been developed (see Figure 1). 


\section{Perceived Value of a Service \\ 1) Behavioral Price \\ 2) Monetary Price \\ 3) Emotional Response \\ 4) Quality \\ 5) Reputation}

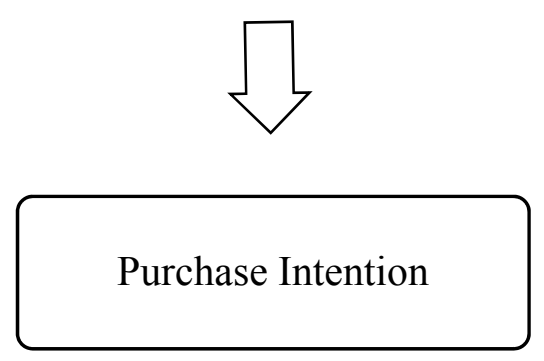

Figure1. Study Model: Perceived Value in the Service Choice Process

\section{Measurement Method and Scales}

This study implemented a primary field survey design and developed a questionnaire based on previous research to test the hypotheses. The questionnaire consisted of three sections: (1) perceived value of fast-food restaurants; (2) purchase intention; (3) demographic information. The first and second sections were assessed based on established factors of perceived value from Petrick's work (2002).

The first section of the questionnaire measured five categories of perceived value: quality, emotional response, monetary price, behavioral price and reputation, using a fivepoint Likert-type scales ranging from 1 (very low) to 5 (very high). First, quality variables were assessed with four items: "is outstanding quality", "is very reliable", "is very dependable, and “is very consistent." Next, emotional response variables included five items: "makes me feel good", "gives me pleasure", "gives me a sense of joy", "makes me feel delighted", and "gives me happiness." Third, six items used to measure 
monetary price variables: "is a good buy", "is worth the money", "is fairly priced", "is reasonably priced", "is economical”, and "appears to be a good bargain." Fourth, behavioral price variables were investigated with 5 items: "is easy to buy", "required little energy to purchase", "is easy to shop for", "required little effort to buy", and "is easily bought”. Lastly, reputation variables involved five items: "has good reputation", "is well respected", "is well thought of", and "is reputable."

The second section of the questionnaire investigated levels of purchase intention. All scales in the second section were assessed on a five point-Likert type scale, where 1 equals to "Not at all likely" and 5 equals to "Extremely likely." Respondents were requested to rate the level of their agreement with the following three statements: "Willing to visit the fast-food restaurant in the future", "Visit the fast-food restaurant", and "Recommend the fast-food restaurant to people you know." The third part of the questionnaire included questions related to the respondent's demographic information such as gender, marital status, age, annual family income, ethnicity, and highest level of education. Table 3 summarizes the constructs and items of perceived value used in the questionnaire.

Table 3

Constructs and Items of the Questionnaire

\begin{tabular}{|c|c|}
\hline Construct & Measurement items \\
\hline Quality & $\begin{array}{ll}\text { - } & \text { is outstanding quality } \\
\text { - } & \text { is very reliable } \\
\text { - } & \text { is very dependable } \\
\text { - } & \text { is very consistent }\end{array}$ \\
\hline Emotional Response & $\begin{array}{ll}\text { - } & \text { makes me feel good } \\
\text { - } & \text { gives me pleasure } \\
\text { - } & \text { gives me a sense of joy }\end{array}$ \\
\hline
\end{tabular}




\begin{tabular}{|c|c|}
\hline & $\begin{array}{ll}- & \text { makes me feel delighted } \\
\text { - } & \text { gives me happiness }\end{array}$ \\
\hline Monetary Price & $\begin{array}{l}\text { - } \quad \text { is a good buy } \\
\text { - } \quad \text { is worth the money } \\
\text { - } \quad \text { is fairly priced } \\
\text { - } \quad \text { is reasonably priced } \\
\text { - } \quad \text { is economical } \\
\text { - } \quad \text { appears to be a good bargain }\end{array}$ \\
\hline Behavioral Price & $\begin{array}{ll}\text { - } & \text { is easy to buy } \\
\text { - } & \text { required little energy to purchase } \\
\text { - } & \text { is easy to shop for } \\
\text { - } & \text { required little effort to buy } \\
\text { - } & \text { is easily bought }\end{array}$ \\
\hline Reputation & $\begin{array}{l}\text { - } \quad \text { has good reputation } \\
\text { - } \quad \text { is well respected } \\
\text { - } \text { is well thought of } \\
\text { - } \quad \text { has status } \\
\text { - } \quad \text { is reputable }\end{array}$ \\
\hline
\end{tabular}

\section{Sample and Data Collection}

The current study researched fast-food restaurant franchises. Among the lot of fast-food restaurant franchises, six fast-food restaurant brands were selected from the list of "the Top 50 Brands in Quick Service and Fast Casual” (Quick Service Restaurant Magazine, 2014). The article is published by the Quick Service Restaurant Magazine that reports fast-food restaurant industry news. The listing criteria of the Top 50 Brands in Quick Service and Fast Casual consisted of 2013 U.S. system wide sales, 2013 U.S. average sales per unit, number of franchised units in 2013, number of company units in 2013, total units in 2013 and total change in units from 2012. Of all the criteria, the U.S. system wide sales were regarded as the most important factor when they ranked fast-food restaurants. This study chose the following six fast-food restaurant brands in order of 2013 U. S. system wide sales: 
(1) McDonald's

(2) Subway

(3) Starbucks

(4) Wendy's

(5) Burger King

(6) Taco Bell

The reason why the study chose these top six highest fast-food restaurants in terms of sale is that higher sales mean better popularity and universality at that time. For this reason, this study did not include some renowned fast-food brands such as KFC, Pizza Hut, and Chipotle. Even though the fast-food restaurant brand that this study chose is not reflective of the whole fast-food restaurant industry, this study used this brand to indicate how fast-food restaurants can be perceived and how to measure perceived value.

Prior to data collection, a protocol explaining the study was submitted to Institutional Review Board (IRB) of Florida International University. Approval was granted by the IRB to conduct research involving human subjects. The sample for this study was composed of South Floridians. Data for this study was collected from two channels, online and offline survey, from January 17 to February 17, 2015. The researchers distributed survey questionnaires and sent out e-mails or texts embedding a link to a consent form and questionnaire to the potential participants. Overall, 349 questionnaires were collected for this research. After excluding 46 invalid surveys, 303 responses were kept for further analysis. The overall valid response rate was $86.8 \%$. 


\section{Data Analysis Method}

Descriptive statistics such as frequencies and percentages were used to compare the perceived value among fast-food restaurants and examine the respondent's individual demographic information. In addition, the mean values for each variable were analyzed. Data was entered into the Statistical Packages for Social Sciences (SPSS) 22.0 for Windows. This study first performed multivariate analysis of variance (MANOVA) to determine whether there were differences between fast-food restaurants on its overall perceived value. The assumptions that were needed to be assessed before performing multivariate analysis of variance were the following: multivariate normality, homogeneity of the covariance matrices, and independence of observations. Multivariate normality assumes that each variable and all linear combinations of the variables are normally distributed and was tested using the Kolmogorov Smirnov test. Homogeneity of the covariance matrices assumption was assessed using Box's M test. Assumptions are violated if Box's M is significant. Lastly, the independence assumes that a subject's score on the dependent measures should not be influenced by or related to scores of other subjects in the condition or level and was tested with an intraclass correlation coefficient (Hair, Joseph F. Jr., Black, William C., Babin, Barry J., \& Anderson, Rolph E., 2010).

Next, factor analysis was performed to condense the large data set into a few constructs and regression analysis was performed to test how a fast-food restaurant's perceived value affects a customer's purchase intention. Factor analysis is designed for interval data. The variables should be linearly related and moderately correlated to each other. Scatter plots of paired variables were checked for linearity and Bartlett's test was checked for sufficient correlation between variables (Hair et al., 2010). 
The assumptions that needed to be checked before performing regression analysis were the following: normality, independence of observations, linearity, constant variance, and multicollinearity. All data was screened for outliers and scatter plots were reviewed of nonlinear distributions and relationships. Normal probability plots were examined for normal distribution in each performance as well. The independence assumption was checked to make sure that there is no relationship between the observations in the different groups and between the observations within the same group. Model summary of Durbin-Watson was checked in each case for the independence of observations. The numbers were ranged from 0 to 4 and if it was close to 2 , that was not considered to be problematic. Linearity was checked by producing all partial plots. Constant variance was verified by checking residual plots. Finally, collinearity was checked by observing VIF values. VIF values higher than 5 is problematic (Hair et al., 2010).

\section{Summary}

This study designed a questionnaire and conducted a survey to test the hypotheses. A total number of six fast-food restaurants (McDonalds, Subway, Starbucks, Wendy's, Burger King, and Taco Bell) were chosen. Twenty five items were used to measure perceived service value. Factor analysis was performed to condense the large set of the items into five underlying constructs (quality, emotional response, monetary price, behavioral price, and reputation). Descriptive statistics was used to identify the highest perceived value among the selected fast-food restaurants. Lastly, multivariate analysis of variance (MANOVA) and multiple regression analysis were conducted to test the study hypotheses. 


\section{CHAPTER IV}

\section{RESULTS}

\section{Introduction}

This chapter shows the data analysis and the results of this study. The demographic information of the participants is described in the first section. The second section presents the results of the six brand's perceived value with descriptive statistics and the third section describes results of reliability and validity tests. Lastly, the results of the hypotheses tests using multivariate analysis of variance (MANOVA) and multiple linear regression analysis are also presented in the fourth section.

\section{Sample Profile}

A total of 349 questionnaires were collected for this study. After deleting 46 invalid surveys, 303 responses were kept for further analysis. About $31 \%$ of the respondents were male and $69 \%$ were female (see Table 4 ). The marital status of the majority of the respondents was either single or married and only a few were divorced or separated. For example, $80.5 \%$ of the respondents were single and $15.8 \%$ were married, $2.3 \%$ of the respondents were divorced and only $0.3 \%$ were separated (see Table 5 ).

\section{Table 4}

\section{Gender of Respondents}

\begin{tabular}{lcr}
\hline Gender & Frequency & Percentage (\%) \\
\hline Male & 94 & 31.02 \\
Female & 209 & 68.98 \\
Total & 303 & 100.00 \\
\hline
\end{tabular}


Table 5

Marital Status

\begin{tabular}{lcr}
\hline Marital Status & Frequency & Percentage (\%) \\
\hline Single & 244 & 80.53 \\
Married & 48 & 15.84 \\
Divorced & 7 & 2.31 \\
Separated & 1 & 0.33 \\
Other & 3 & 0.99 \\
Total & 303 & 100.00 \\
\hline
\end{tabular}

The age of the respondents was separated into four different groups. More than half of the participants' ages ranged from 18 to 25 years old (57.8\%). 28.7\% were 26 to 35 years old, $7.3 \%$ were 36 to 45 years old, and $6.2 \%$ were over 46 years old (see Table $6)$.

Table 6

Age of Respondents

\begin{tabular}{lcr}
\hline Age & Frequency & Percentage (\%) \\
\hline $18-25$ & 175 & 57.76 \\
$26-35$ & 87 & 28.71 \\
$36-45$ & 22 & 7.26 \\
46 and over & 19 & 6.27 \\
Total & 303 & 100.00 \\
\hline
\end{tabular}


With regards to annual family income, $41.9 \%$ of the respondents had an annual family income of less $\$ 39,999$. Approximately $20 \%$ had an annual family income of over $\$ 40,000$ to $\$ 79,999,10.6 \%$ had between $\$ 80,000$ and $\$ 119,999,5.0 \%$ had between $\$ 120,000$ and $\$ 159,999$, and $1.7 \%$ had between $\$ 160,000$ and $\$ 199,999$. Fewer than $2.3 \%$ had an annual household income of more than $\$ 200,000$. About $19 \%$ of the respondents refused to answer their family income (see Table 7).

Table 7

Annual Family Income

\begin{tabular}{lcr}
\hline Income & Frequency & Percentage (\%) \\
\hline$\$ 39,999$ or less & 127 & 41.91 \\
$\$ 40,000-\$ 79,999$ & 60 & 19.80 \\
$\$ 80,000-\$ 119,999$ & 32 & 10.56 \\
$\$ 120,000-\$ 159,999$ & 15 & 4.95 \\
$\$ 160,000-\$ 199,999$ & 5 & 1.65 \\
$\$ 200,000$ and over & 7 & 2.31 \\
I respectfully decline to answer & 57 & 18.81 \\
Total & 303 & 100.00 \\
\hline
\end{tabular}

Based on their race, respondents can be divided into five groups. Approximately $16 \%$ of the participants were Caucasian (Non-Hispanic), $16.8 \%$ were African American/Black (Non-Hispanic), 32.0\% were Hispanic, 30.0\% were Asian or Pacific Islander, and $5.3 \%$ were mixed or other race as depicted in Table 8. 
Table 8

Race of Respondents

\begin{tabular}{lcr}
\hline Nationality & Frequency & \multicolumn{2}{c}{ Percentage (\%) } \\
\hline Caucasian (Non-Hispanic) & 48 & 15.84 \\
African American/Black (Non- & 51 & 16.83 \\
Hispanic) & 97 & 32.01 \\
Hispanic & 91 & 30.03 \\
Asian or Pacific Islander & 16 & 5.28 \\
Mixed Race/Other & 303 & 100.00 \\
Total & & \\
\hline
\end{tabular}

Nearly $18 \%$ of the participants had completed high school, 26.1 had an associate's degree, 28.4\% had a bachelor's degree, 17.5\% had earned a Master's degree, 5.9\% had Doctoral degree, and 4.6\% had other education (see Table 9).

Table 9

Highest Education Degreed

\begin{tabular}{lcr} 
Education & Frequency & \multicolumn{2}{c}{ Percentage (\%) } \\
\hline High School & 53 & 17.49 \\
Associate's Degree & 79 & 26.07 \\
Bachelor's Degree & 86 & 28.38 \\
Master's Degree & 53 & 17.49 \\
Doctoral Degree & 18 & 5.94 \\
Other Education/Trade & 14 & 4.62 \\
Total & 303 & 100.00 \\
\hline
\end{tabular}




\section{Comparison of Fast-food Restaurant Perceived Value}

The detailed results of the mean scores of fast-food restaurants with respect to each perceived value item summarized in Table 10. In terms of quality and emotional response: Starbucks $(M=3.80$ and 3.64) topped the list followed by Subway $(M=3.49$ and 2.99), Wendy's ( $M=3.80$ and 3.64), Burger King ( $M=3.80$ and 3.64), McDonald's $(\mathrm{M}=3.80$ and 3.64), and Taco Bell $(\mathrm{M}=3.80$ and 3.64) respectively. Regarding monetary price, Subway $(\mathrm{M}=3.47)$ was the leader followed by McDonald's $(\mathrm{M}=3.28)$, Wendy's $(\mathrm{M}=3.26)$, Burger King $(\mathrm{M}=3.13)$, and Taco Bell $(\mathrm{M}=2.93)$ respectively. On the other hand, Starbucks $(M=2.73)$ ranked the last in terms of monetary price. Concerning behavioral price, McDonald's $(M=4.09)$ turned out to be the best fast-food restaurant. Subway $(M=3.77)$, Burger King $(M=3.74)$, Wendy's $(M=3.73)$, Starbucks $(M=3.70)$, and Taco Bell (M=3.38) ranked second, third, fourth, fifth and sixth place, respectively. Lastly, with regards to reputation, Starbucks $(M=4.24)$ ranked the highest followed by Subway $(\mathrm{M}=3.66)$, Wendy's $(\mathrm{M}=3.27)$, Burger King $(\mathrm{M}=3.00)$, McDonald's $(\mathrm{M}=2.89)$, and Taco Bell $(\mathrm{M}=2.51)$ respectively.

Table 10

Mean Scores for Perceived Service Value Dimensions

\begin{tabular}{lcccccc}
\hline & Quality & $\begin{array}{c}\text { Emotional } \\
\text { Response }\end{array}$ & $\begin{array}{c}\text { Monetary } \\
\text { Price }\end{array}$ & $\begin{array}{c}\text { Behavioral } \\
\text { Price }\end{array}$ & Reputation & Total \\
\hline McDonald's & $2.75(5)$ & $2.23(5)$ & $3.28(2)$ & $4.09(1)$ & $2.89(5)$ & $3.05(4)$ \\
Subway & $3.49(2)$ & $2.99(2)$ & $3.47(1)$ & $3.77(2)$ & $3.66(2)$ & $3.48(2)$ \\
Starbucks & $3.80(1)$ & $3.64(1)$ & $2.73(6)$ & $3.70(5)$ & $4.24(1)$ & $3.62(1)$ \\
Wendy's & $3.19(3)$ & $2.72(3)$ & $3.26(3)$ & $3.73(4)$ & $3.27(3)$ & $3.23(3)$ \\
Burger King & $2.84(4)$ & $2.46(4)$ & $3.13(4)$ & $3.74(3)$ & $3.00(4)$ & $3.03(5)$
\end{tabular}




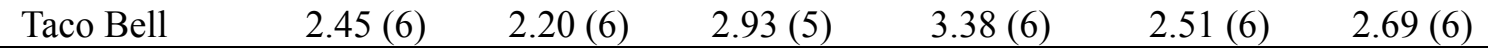

Note. Each value in the parenthesis indicates the ranking.

\section{Reliability and Validity tests}

The reliability in this research was measured by the reliability analysis on SPSS 22.0. The Cronbach alpha values ranged from 0.92 to 0.98 . The Cronbach alpha index ranges from 0 to 1 and higher alpha value indicates higher internal consistency. The generally agreed lower limit of the Cronbach's alpha value is 0.70 (Hair et al., 2010). As seen in Table 11 and 12, all the variables had acceptable alpha values that were values very close to 1 .

Table 11

Reliability of Perceived Service Value Items

\begin{tabular}{|c|c|c|c|}
\hline Items & $\mathrm{M}$ & SD & Cronbach's alpha \\
\hline Quality & & & 0.92 \\
\hline is outstanding quality & 2.87 & 0.72 & \\
\hline is very reliable & 3.11 & 0.80 & \\
\hline is very dependable & 3.07 & 0.84 & \\
\hline is very consistent & 3.24 & 0.85 & \\
\hline Emotional Response & & & 0.98 \\
\hline makes me feel good & 2.77 & 0.77 & \\
\hline gives me pleasure & 2.76 & 0.79 & \\
\hline gives me a sense of joy & 2.68 & 0.82 & \\
\hline makes me feel delighted & 2.66 & 0.81 & \\
\hline Gives me happiness & 2.67 & 0.83 & \\
\hline Monetary Price & & & 0.95 \\
\hline is a good buy & 3.08 & 0.80 & \\
\hline is worth the money & 3.01 & 0.80 & \\
\hline is fairly priced & 3.14 & 0.77 & \\
\hline is reasonably priced & 3.18 & 0.76 & \\
\hline
\end{tabular}


is economical

appears to be a good bargain

Behavioral Price

is easy to buy

required little energy to purchase

is easy to shop for

required little effort to buy

is easily bought
3.23

3.16

0.77

0.77

0.93

$3.82 \quad 1.06$

$3.64 \quad 0.88$

$3.77 \quad 0.80$

$3.65 \quad 0.88$

$3.77 \quad 0.84$

Reputation

0.96

has good reputation

$3.25 \quad 0.75$

is well respected

$3.23 \quad 0.78$

is well thought of

$3.19 \quad 0.75$

has status

$3.35 \quad 0.81$

is reputable

$3.29 \quad 0.82$

The factor's content validity was established through the rigorous process of developing the questionnaire and theoretical support from the literature review.

Furthermore, the results of the factor analysis suggest the construct validity because all items loaded acceptably. The Kaiser-Meyer-Olkin value from the KMO and Bartlett's test measured of sampling adequacy and the value was greater than a threshold score of 0.70 , which was excellent. This shows that the selected factors were overall acceptable to be measured for the study (Nunally, 1978).

Table 12

Reliability of Purchase Intention Items

\begin{tabular}{lll} 
Items & M & SD Cronbach's alpha \\
\hline
\end{tabular}

Purchase Intention

0.91

Willing to visit the fast-

food restaurant in the future.

$3.33 \quad 1.36$ 
Visit the fast-food restaurant.

Recommend the fast-

food restaurant to people you know.
$3.34 \quad 1.31$

$2.89 \quad 1.40$

\section{Testing of Hypotheses}

\section{Multivariate Analysis of Variance (MANOVA)}

The first hypothesis was built to examine how perceived value differs significantly among different fast-food restaurant brands. In order to test the hypothesis, multivariate analysis of variance (MANOVA) was used with perceived value as the dependent variable and six fast-food restaurant franchises as the independent variable.

H1: Perceived value differ significantly among different fast-food restaurants brands.

As can be seen in Table 13, the results show that the perceived service value of fast-food restaurant franchises are significantly different (Wilks' $\lambda=0.58, F=42.82, p<$ 0.05). Thus, H1 was supported.

Table 13

Multivariate Tests

\begin{tabular}{lrrrr}
\hline & Wilk's Lambda & F & Sig. & Partial Eta Squared \\
\hline Fast-food brands & 0.58 & 42.82 & $0.00^{*}$ & 0.11 \\
\hline Note. ${ }^{*} \mathrm{p}<0.05$. & & & &
\end{tabular}

Given the significance of the overall test, follow-up ANOVAs were performed. Significant univariate effects for fast-food restaurant franchises were obtained for five perceived value dimensions (see Table 14). Perceived value was influenced by fast-food restaurant franchises on all five dimensions; quality $(\mathrm{F}=72.33, \mathrm{p}<0.05)$; emotional 
response $(\mathrm{F}=71.80, \mathrm{p}<0.05)$; monetary price $(\mathrm{F}=18.50, \mathrm{p}<0.05)$; behavioral price $(\mathrm{F}$ $=11.74, \mathrm{p}<0.05) ;$ and reputation $(\mathrm{F}=102.87, \mathrm{p}<0.05)$.

Table 14

\section{Univariate Main Effect}

\begin{tabular}{lccc}
\hline Dependent Variable & F & Sig. & Partial Eta Squared \\
\hline Quality & 72.33 & $0.00^{*}$ & 0.17 \\
Emotional Response & 71.80 & $0.00^{*}$ & 0.17 \\
Monetary Price & 18.50 & $0.00^{*}$ & 0.05 \\
Behavioral Price & 11.74 & $0.00^{*}$ & 0.03 \\
Reputation & 102.87 & $0.00^{*}$ & 0.22 \\
\hline Note. ${ }^{*} \mathrm{p}<0.05$. & & &
\end{tabular}

Table 15 shows the results of follow-up post hoc tests to observe the pairwise difference for quality. In regards to quality, significant differences were found across all brands except between McDonald's and Burger King. McDonalds (M=2.75) was significantly different from Subway ( $M=3.49)$, Starbucks ( $M=3.80)$, Wendy's ( $M=3.19)$, and Taco Bell $(\mathrm{M}=2.45)$. Subway $(\mathrm{M}=3.49)$ was significantly different from Starbucks $(\mathrm{M}=3.80)$, Wendy's $(\mathrm{M}=3.19)$, Burger King $(\mathrm{M}=2.84)$, and Taco Bell $(\mathrm{M}=2.45)$. Starbucks ( $M=3.80)$ was significantly different from Wendy's (M=3.188), Burger King $(\mathrm{M}=2.84)$, and Taco Bell $(\mathrm{M}=2.45)$. Wendy's $(\mathrm{M}=3.19)$ was significantly different from Burger King $(M=2.84)$ and Taco Bell $(M=2.45)$. Lastly, significant differences were found between Burger King $(\mathrm{M}=2.84)$ and Taco Bell $(\mathrm{M}=2.45)$. 
Table 15

Post Hoc Tests (DV: Quality)

\begin{tabular}{|c|c|c|c|c|}
\hline \multicolumn{2}{|c|}{ Fast-food Restaurants } & Mean Difference & Std. Error & Sig. \\
\hline \multicolumn{5}{|c|}{ Dependent variable: Quality } \\
\hline \multirow[t]{5}{*}{ McDonald's } & Subway & $-0.74^{*}$ & 0.08 & $0.00 *$ \\
\hline & Starbucks & $-1.05^{*}$ & 0.08 & $0.00 *$ \\
\hline & Wendy's & $-0.44^{*}$ & 0.08 & $0.00 *$ \\
\hline & Burger King & -0.09 & 0.08 & 0.89 \\
\hline & Taco Bell & $0.30^{*}$ & 0.08 & $0.00 *$ \\
\hline \multirow[t]{5}{*}{ Subway } & McDonald's & $0.74^{*}$ & 0.08 & $0.00 *$ \\
\hline & Starbucks & $-0.31^{*}$ & 0.08 & $0.00 *$ \\
\hline & Wendy's & $0.30^{*}$ & 0.08 & $0.00 *$ \\
\hline & Burger King & $0.65^{*}$ & 0.08 & $0.00 *$ \\
\hline & Taco Bell & $1.04^{*}$ & 0.08 & $0.00 *$ \\
\hline \multirow[t]{5}{*}{ Starbucks } & McDonald's & $1.05^{*}$ & 0.08 & $0.00 *$ \\
\hline & Subway & $0.31^{*}$ & 0.08 & $0.00 *$ \\
\hline & Wendy's & $0.61^{*}$ & 0.08 & $0.00 *$ \\
\hline & Burger King & $0.95^{*}$ & 0.08 & $0.00 *$ \\
\hline & Taco Bell & $1.35^{*}$ & 0.08 & $0.00 *$ \\
\hline \multirow[t]{5}{*}{ Wendy's } & McDonald's & $0.44^{*}$ & 0.08 & $0.00 *$ \\
\hline & Subway & $-0.30^{*}$ & 0.08 & $0.00 *$ \\
\hline & Starbucks & $-0.61^{*}$ & 0.08 & $0.00 *$ \\
\hline & Burger King & $0.35^{*}$ & 0.08 & $0.00 *$ \\
\hline & Taco Bell & $0.74^{*}$ & 0.08 & $0.00 *$ \\
\hline \multirow[t]{5}{*}{ Burger King } & McDonald's & 0.09 & 0.08 & 0.89 \\
\hline & Subway & $-0.65^{*}$ & 0.08 & $0.00 *$ \\
\hline & Starbucks & $-0.95^{*}$ & 0.08 & $0.00 *$ \\
\hline & Wendy's & $-0.35^{*}$ & 0.08 & $0.00 *$ \\
\hline & Taco Bell & $0.39^{*}$ & 0.08 & $0.00 *$ \\
\hline \multirow[t]{5}{*}{ Taco Bell } & McDonald's & $-0.30^{*}$ & 0.08 & $0.00 *$ \\
\hline & Subway & $-1.04^{*}$ & 0.08 & $0.00 *$ \\
\hline & Starbucks & $-1.35^{*}$ & 0.08 & $0.00 *$ \\
\hline & Wendy's & $-0.74^{*}$ & 0.08 & $0.00 *$ \\
\hline & Burger King & $-0.39^{*}$ & 0.08 & $0.00 *$ \\
\hline
\end{tabular}

Note. ${ }^{*}$ The mean difference is significant at the 0.05 level. 
Table 16 shows the results of follow-up post hoc tests to observe the pairwise difference for emotional response. Regarding emotional response, significant statistical differences were found across all brands except between McDonald's and Taco Bell; Burger King and McDonald's and Wendy's, and Taco bell. McDonalds $(\mathrm{M=2.23)}$ was significantly different from Subway ( $M=2.99)$, Starbucks $(M=3.64)$, and Wendy's $(M=2.72)$. Subway $(M=2.99)$ was significantly different from Starbucks $(M=3.64)$, Wendy's ( $M=2.72)$, Burger King $(M=2.46)$, and Taco Bell $(M=2.20)$. Starbucks $(M=3.64)$ was significantly different from Wendy's ( $M=2.72)$, Burger King $(\mathrm{M}=2.46)$ and Taco Bell $(M=2.20)$. Wendy's $(M=2.72)$ was significantly different from Taco Bell $(M=2.20)$.

Table 16

Post Hoc Tests (DV: Emotional Response)

\begin{tabular}{llccc} 
Fast-food Restaurants & & Mean Difference & Std. Error & Sig. \\
\hline Dependent variable: & Emotional Response & & & \\
McDonald's & Subway & $-0.76^{*}$ & 0.09 & $0.00^{*}$ \\
& Starbucks & $-1.42^{*}$ & 0.09 & $0.00^{*}$ \\
& Wendy's & $-0.49^{*}$ & 0.09 & $0.00^{*}$ \\
& Burger King & -0.23 & 0.09 & 0.12 \\
Subway & Taco Bell & 0.03 & 0.09 & 1.00 \\
& McDonald's & $0.76^{*}$ & 0.09 & $0.00^{*}$ \\
& Starbucks & $-0.65^{*}$ & 0.09 & $0.00^{*}$ \\
& Wendy's & $0.27^{*}$ & 0.09 & $0.04^{*}$ \\
& Burger King & $0.53^{*}$ & 0.09 & $0.00^{*}$ \\
Starbucks & Taco Bell & $0.79^{*}$ & 0.09 & $0.00^{*}$ \\
& McDonald's & $1.42^{*}$ & 0.09 & $0.00^{*}$ \\
& Subway & $0.65^{*}$ & 0.09 & $0.00^{*}$ \\
& Wendy's & $0.93^{*}$ & 0.09 & $0.00^{*}$ \\
\multirow{5}{*}{ Wendy's } & Burger King & $1.18^{*}$ & 0.09 & $0.00^{*}$ \\
& Taco Bell & $1.44^{*}$ & 0.09 & $0.00^{*}$ \\
& McDonald's & $0.49^{*}$ & 0.09 & $0.00^{*}$ \\
& Subway & $-0.27^{*}$ & 0.09 & $0.04^{*}$ \\
\hline
\end{tabular}




\begin{tabular}{rlcrr}
\hline & Starbucks & $-0.93^{*}$ & 0.09 & $0.00^{*}$ \\
\multirow{3}{*}{ Burger King } & Burger King & 0.26 & 0.09 & 0.06 \\
& Taco Bell & $0.53^{*}$ & 0.09 & $0.00^{*}$ \\
& McDonald's & 0.23 & 0.09 & 0.12 \\
& Subway & $-0.53^{*}$ & 0.09 & $0.00^{*}$ \\
& Starbucks & $-1.18^{*}$ & 0.09 & $0.00^{*}$ \\
& Wendy's & -0.26 & 0.09 & 0.06 \\
& Taco Bell & 0.26 & 0.09 & 0.05 \\
& McDonald's & -0.03 & 0.09 & 1.00 \\
& Subway & $-0.79^{*}$ & 0.09 & $0.00^{*}$ \\
& Starbucks & $-1.44^{*}$ & 0.09 & $0.00^{*}$ \\
& Wendy's & $-0.52^{*}$ & 0.09 & $0.00^{*}$ \\
& Burger King & -0.26 & 0.09 & 0.05 \\
\hline
\end{tabular}

Note. ${ }^{*}$ The mean difference is significant at the 0.05 level.

Table 17 shows the results of follow-up post hoc tests to observe the pairwise difference for monetary price. Concerning Monetary Price, statistically significant differences were found between McDonald's, Starbucks, and Taco Bell;Subway and Starbucks, Burger King, Taco Bell; Starbucks and Wendy’s, Burger King; and Wendy’s and Taco Bell. McDonalds $(\mathrm{M}=3.28)$ was significantly different from Starbucks $(\mathrm{M}=2.73)$ and Taco Bell $(M=2.93)$. Subway $(M=3.47)$ was significantly different from Starbucks $(M=2.73)$, Burger King $(M=3.13)$, and Taco Bell $(M=2.93)$. Starbucks $(M=2.73)$ was significantly different from Wendy’s $(\mathrm{M}=3.26)$ and Burger King $(\mathrm{M}=3.13)$. Lastly, significant differences were found between Wendy's $(M=3.26)$ and Taco Bell $(M=2.93)$. Table 17

Post Hoc Tests (DV: Monetary Price)

\begin{tabular}{|c|c|c|c|c|}
\hline Fast-food Re & & Mean Difference & Std. Error & Sig. \\
\hline Dependent vc & Ionetary $\mathrm{Pr}$ & & & \\
\hline McDonald's & Subway & -0.19 & 0.08 & 0.24 \\
\hline & Starbucks & $0.55^{*}$ & 0.08 & $0.00 *$ \\
\hline
\end{tabular}




\begin{tabular}{|c|c|c|c|c|}
\hline & Wendy's & 0.02 & 0.08 & 1.00 \\
\hline & Burger King & 0.15 & 0.08 & 0.54 \\
\hline & Taco Bell & $0.35^{*}$ & 0.08 & $0.00 *$ \\
\hline \multirow[t]{5}{*}{ Subway } & McDonald's & 0.19 & 0.08 & 0.24 \\
\hline & Starbucks & $0.74^{*}$ & 0.08 & $0.00 *$ \\
\hline & Wendy's & 0.21 & 0.08 & 0.15 \\
\hline & Burger King & $0.34^{*}$ & 0.08 & $0.00 *$ \\
\hline & Taco Bell & $0.55^{*}$ & 0.08 & $0.00 *$ \\
\hline \multirow[t]{5}{*}{ Starbucks } & McDonald's & $-0.55^{*}$ & 0.08 & $0.00^{*}$ \\
\hline & Subway & $-0.74^{*}$ & 0.08 & $0.00 *$ \\
\hline & Wendy's & $-0.53^{*}$ & 0.08 & $0.00^{*}$ \\
\hline & Burger King & $-0.40^{*}$ & 0.08 & $0.00 *$ \\
\hline & Taco Bell & -0.19 & 0.08 & 0.24 \\
\hline \multirow[t]{5}{*}{ Wendy's } & McDonald's & -0.02 & 0.08 & 1.00 \\
\hline & Subway & -0.21 & 0.08 & 0.15 \\
\hline & Starbucks & $0.53^{*}$ & 0.08 & $0.00 *$ \\
\hline & Burger King & 0.13 & 0.08 & 0.69 \\
\hline & Taco Bell & $0.33^{*}$ & 0.08 & $0.00 *$ \\
\hline \multirow[t]{5}{*}{ Burger King } & McDonald's & -0.15 & 0.08 & 0.54 \\
\hline & Subway & $-0.34^{*}$ & 0.08 & $0.00 *$ \\
\hline & Starbucks & $0.40^{*}$ & 0.08 & $0.00^{*}$ \\
\hline & Wendy's & -0.13 & 0.08 & 0.69 \\
\hline & Taco Bell & 0.21 & 0.08 & 0.18 \\
\hline \multirow[t]{5}{*}{ Taco Bell } & McDonald's & $-0.35^{*}$ & 0.08 & $0.00^{*}$ \\
\hline & Subway & $-0.55^{*}$ & 0.08 & $0.00 *$ \\
\hline & Starbucks & 0.19 & 0.08 & 0.24 \\
\hline & Wendy's & $-0.33^{*}$ & 0.08 & $0.00 *$ \\
\hline & Burger King & -0.21 & 0.08 & 0.18 \\
\hline
\end{tabular}

Note. * The mean difference is significant at the 0.05 level.

Table 18 shows the results of follow-up post hoc tests to observe the pairwise

difference for behavioral price. With regards to Behavioral Price, statistically significant differences were found all brands except between Subway and Starbucks, Wendy's and Burger King; Starbucks, Wendy's, and Burger King; and Wendy’s and Burger King. McDonalds $(M=4.09)$ was significantly different from Subway $(M=3.77)$, Starbucks $(M=3.70)$, Wendy's (M=3.73), Burger King (3.74) and Taco Bell (M=3.38). Subway 
$(M=3.77)$ was significantly different from Taco Bell $(M=3.38)$. Starbucks $(M=3.70)$ was significantly different from Taco Bell $(\mathrm{M}=3.38)$. Wendy's $(\mathrm{M}=3.73)$ was significantly different from Taco Bell $(M=3.38)$. Lastly, significant differences were found between Burger King (3.74) and Taco Bell (M=3.38).

Table 18

Post Hoc Tests (DV: Behavioral Price)

\begin{tabular}{llrrr}
\multicolumn{1}{l}{ Fast-food Restaurants } & \multicolumn{2}{c}{ Mean Difference } & Std. Error & Sig. \\
\hline Dependent variable: & Behavioral Price & & & \\
McDonald's & Subway & $0.32^{*}$ & 0.09 & $0.01^{*}$ \\
& Starbucks & $0.39^{*}$ & 0.09 & $0.00^{*}$ \\
& Wendy's & $0.36^{*}$ & 0.09 & $0.00^{*}$ \\
& Burger King & $0.35^{*}$ & 0.09 & $0.00^{*}$ \\
Subway & Taco Bell & $0.71^{*}$ & 0.09 & $0.00^{*}$ \\
& McDonald's & $-0.32^{*}$ & 0.09 & $0.01^{*}$ \\
& Starbucks & 0.07 & 0.09 & 0.98 \\
& Wendy's & 0.04 & 0.09 & 1.00 \\
\multirow{5}{*}{ Starbucks } & Burger King & 0.03 & 0.09 & 1.00 \\
& Taco Bell & $0.39^{*}$ & 0.09 & $0.00^{*}$ \\
& McDonald's & $-0.39^{*}$ & 0.09 & $0.00^{*}$ \\
& Subway & -0.07 & 0.09 & 0.98 \\
Wendy's & Wendy's & -0.03 & 0.09 & 1.00 \\
& Burger King & -0.04 & 0.09 & 1.00 \\
& Taco Bell & $0.33^{*}$ & 0.09 & $0.01^{*}$ \\
& McDonald's & $-0.36^{*}$ & 0.09 & $0.00^{*}$ \\
& Subway & -0.04 & 0.09 & 1.00 \\
& Starbucks & 0.03 & 0.09 & 1.00 \\
Burger King & Burger King & -0.01 & 0.09 & 1.00 \\
& Taco Bell & $0.35^{*}$ & 0.09 & $0.00^{*}$ \\
& McDonald's & $-0.35^{*}$ & 0.09 & $0.00^{*}$ \\
& Subway & -0.03 & 0.09 & 1.00 \\
& Starbucks & 0.04 & 0.09 & 1.00 \\
& Wendy's & 0.01 & 0.09 & 1.00 \\
& Taco Bell & $0.36^{*}$ & 0.09 & $0.00^{*}$ \\
\hline & & & &
\end{tabular}




\begin{tabular}{lllll}
\hline Taco Bell & McDonald's & $-0.71^{*}$ & 0.09 & $0.00^{*}$ \\
Subway & $-0.39^{*}$ & 0.09 & $0.00^{*}$ \\
& Starbucks & $-0.33^{*}$ & 0.09 & $0.01^{*}$ \\
Wendy's & $-0.35^{*}$ & 0.09 & $0.00^{*}$ \\
& Burger King & $-0.36^{*}$ & 0.09 & $0.00^{*}$ \\
\hline
\end{tabular}

Note. ${ }^{*}$ The mean difference is significant at the 0.05 level.

Table 19 shows the results of follow-up post hoc tests to observe the pairwise difference for reputation. Lastly in terms of Reputation, significant differences were found across all brands except between McDonald's and Burger King. McDonalds $(M=2.89)$ was significantly different from Subway $(M=3.66)$, Starbucks $(M=4.24)$, Wendy's $(M=3.27)$, and Taco Bell $(M=2.51)$. Subway $(M=3.66)$ was significantly different from Starbucks (M=4.24), Wendy's $(M=3.27)$, Burger King $(M=3.00)$ and Taco Bell ( $M=2.51)$. Starbucks $(M=4.24)$ was significantly different from Wendy's $(M=3.27)$, Burger King $(M=3.00)$ and Taco Bell $(M=2.51)$. Wendy's $(M=3.27)$ was significantly different from Burger King $(\mathrm{M}=3.00)$ and Taco Bell $(\mathrm{M}=2.51)$. Lastly, significant differences were found between Burger King $(M=3.00)$ Taco Bell $(M=2.51)$.

Table 19

Post Hoc Tests (DV: Reputation)

\begin{tabular}{llrrr}
\multicolumn{2}{l}{ Fast-food Restaurants } & Mean Difference & Std. Error & \multicolumn{1}{c}{ Sig. } \\
\hline Dependent variable: & Reputation & & & \\
McDonald's & Subway & $-0.77^{*}$ & 0.09 & $0.00^{*}$ \\
& Starbucks & $-1.35^{*}$ & 0.09 & $0.00^{*}$ \\
& Wendy's & $-0.38^{*}$ & 0.09 & $0.00^{*}$ \\
& Burger King & -0.11 & 0.09 & 0.77 \\
Subway & Taco Bell & $0.38^{*}$ & 0.09 & $0.00^{*}$ \\
& McDonald's & $0.77^{*}$ & 0.09 & $0.00^{*}$ \\
& Starbucks & $-0.58^{*}$ & 0.09 & $0.00^{*}$ \\
& Wendy's & $0.40^{*}$ & 0.09 & $0.00^{*}$ \\
\hline
\end{tabular}




\begin{tabular}{|c|c|c|c|c|}
\hline & Burger King & $0.66^{*}$ & 0.09 & $0.00^{*}$ \\
\hline & Taco Bell & $1.16^{*}$ & 0.09 & $0.00 *$ \\
\hline \multirow[t]{5}{*}{ Starbucks } & McDonald's & $1.35^{*}$ & 0.09 & $0.00^{*}$ \\
\hline & Subway & $0.58^{*}$ & 0.09 & $0.00 *$ \\
\hline & Wendy's & $0.98^{*}$ & 0.09 & $0.00 *$ \\
\hline & Burger King & $1.24^{*}$ & 0.09 & $0.00 *$ \\
\hline & Taco Bell & $1.74^{*}$ & 0.09 & $0.00 *$ \\
\hline \multirow[t]{5}{*}{ Wendy's } & McDonald's & $0.38^{*}$ & 0.09 & $0.00^{*}$ \\
\hline & Subway & $-0.40^{*}$ & 0.09 & $0.00^{*}$ \\
\hline & Starbucks & $-0.98^{*}$ & 0.09 & $0.00 *$ \\
\hline & Burger King & $0.26^{*}$ & 0.09 & $0.03 *$ \\
\hline & Taco Bell & $0.76^{*}$ & 0.09 & $0.00 *$ \\
\hline \multirow[t]{5}{*}{ Burger King } & McDonald's & 0.11 & 0.09 & 0.77 \\
\hline & Subway & $-0.66^{*}$ & 0.09 & $0.00 *$ \\
\hline & Starbucks & $-1.24^{*}$ & 0.09 & $0.00 *$ \\
\hline & Wendy's & $-0.26^{*}$ & 0.09 & $0.03 *$ \\
\hline & Taco Bell & $0.50^{*}$ & 0.09 & $0.00^{*}$ \\
\hline \multirow[t]{5}{*}{ Taco Bell } & McDonald's & $-0.38^{*}$ & 0.09 & $0.00 *$ \\
\hline & Subway & $-1.16^{*}$ & 0.09 & $0.00 *$ \\
\hline & Starbucks & $-1.74^{*}$ & 0.09 & $0.00 *$ \\
\hline & Wendy's & $-0.76^{*}$ & 0.09 & $0.00^{*}$ \\
\hline & Burger King & $-0.50^{*}$ & 0.09 & $0.00 *$ \\
\hline
\end{tabular}

Note. ${ }^{*}$ The mean difference is significant at the 0.05 level.

\section{Factor Analysis}

Twenty five items were developed from the literature review to measure the customer's perceived service value of fast-food franchise restaurants. Factor analysis using Varimax with Kaiser normalization was performed to break down the large set of value creation variables into a few underlying constructs and make those items into easily manageable measurements. Table 20 summarizes the Kaiser-Meyer-Olkin value from the KMO and Bartlett's test measured of sampling adequacy. Results indicate that the selected factors were overall appropriate to be measured for the study as the value was higher than 0.70 (Nunally, 1978). 
Table 20

The Kaiser-Meyer-Olkin value

KMO Bartlett's Test

Kaiser-Meyer-Olkin Measure of Sampling Adequecy

0.94

Bartlett's Test of Sphericity

Approx. Chi-Square

9865.47

df

300

Sig.

0.00

As a rule of thumb, variables with loadings of 0.32 and above are commonly interpreted in factor analysis. Comrey and Lee (1992, p. 243) suggested the following of loadings:

a) Loadings in excess of 0.71 (50\% overlapping variance) are considered excellent;

b) Loadings between 0.63 and 0.71 (40\% overlapping variance) are very good;

c) Loadings between 0.55 and 0.63 (30\% overlapping variance) are good;

d) Loadings between 0.45 and 0.55 (20\% overlapping variance) are fair; and

e) Loadings between 0.32 and 0.45 (10\% overlapping variance) are poor.

In the current study, loadings of over 0.45 were accepted and two steps of factor analysis were performed. Components with 1.0 or higher eigenvalues were extracted (see Table 21). Items were grouped into five dimensions as indicated in the literature. The five key dimensions explained a cumulative percentage of $85 \%$. 
Table 21

Total Variance Explained

\begin{tabular}{|c|c|c|c|}
\hline \multirow[t]{2}{*}{ Component } & \multicolumn{3}{|c|}{ Initial Eigenvalues } \\
\hline & Total & $\%$ of Variance & Cumulative $\%$ \\
\hline 1 (Emotional Response) & 13.13 & 52.51 & 52.51 \\
\hline 2 (Monetary Price) & 3.86 & 15.44 & 67.95 \\
\hline 3 (Behavioral Price) & 1.91 & 7.62 & 75.57 \\
\hline 4 (Reputation) & 1.35 & 5.43 & 80.99 \\
\hline 5 (Quality) & 1.03 & 4.11 & 85.10 \\
\hline
\end{tabular}

Note. Principal component analysis was used as the extraction method.

However, one single item (outstanding quality) was categorized in both component 1 (emotional response) and component 5 (quality) (see Table 22). The single item, outstanding quality, showed a loading value higher than 0.50 , meaning it is suitable to be included in either component. Thus, this study performed factor analysis again and included the single item (outstanding quality) into the quality component to keep results consistent with the literature review. Consequently, factor analysis classified the 25 perceived service value items into five factors: (1) Emotional Response; (2) Monetary Price; (3) Behavioral Price; (4) Reputation; and (5) Quality. 
Table 22

Factor Analysis: Rotated Component Matrix

\begin{tabular}{|c|c|c|c|c|c|}
\hline \multirow[b]{2}{*}{ Items } & \multicolumn{5}{|c|}{ Component } \\
\hline & 1 & 2 & 3 & 4 & 5 \\
\hline \multicolumn{6}{|l|}{ Factor 1: Emotional Response } \\
\hline gives me a sense of joy & 0.91 & & & & \\
\hline makes me feel delighted & 0.91 & & & & \\
\hline gives me happiness & 0.89 & & & & \\
\hline gives me pleasure & 0.87 & & & & \\
\hline makes me feel good & 0.85 & & & & \\
\hline \multicolumn{6}{|l|}{ Factor 2: Monetary Price } \\
\hline is reasonably priced & & 0.87 & & & \\
\hline is fairly priced & & 0.86 & & & \\
\hline is economical & & 0.83 & & & \\
\hline appears to be a good bargain & & 0.75 & & & \\
\hline is worth the money & & 0.73 & & & \\
\hline is a good buy & & 0.71 & & & \\
\hline \multicolumn{6}{|l|}{ Factor 3: Behavioral Price } \\
\hline is easy to shop for & & & 0.90 & & \\
\hline required little energy to purchase & & & 0.88 & & \\
\hline required little effort to buy & & & 0.88 & & \\
\hline is easily bought & & & 0.87 & & \\
\hline is easy to buy & & & 0.73 & & \\
\hline \multicolumn{6}{|l|}{ Factor 4: Reputation } \\
\hline has status & & & & 0.81 & \\
\hline is reputable & & & & 0.81 & \\
\hline is well respected & & & & 0.79 & \\
\hline is well thought of & & & & 0.78 & \\
\hline has good reputation & & & & 0.76 & \\
\hline \multicolumn{6}{|l|}{ Factor 5: Quality } \\
\hline is very reliable & & & & & 0.79 \\
\hline is very dependable & & & & & 0.78 \\
\hline is very consistent & & & & & 0.72 \\
\hline is outstanding quality & 0.56 & & & & 0.51 \\
\hline
\end{tabular}

Note. Principal component analysis was used as the extraction method. Rotation Method used in this analysis was Varimax with Kaiser Normalization. 


\section{Multiple Regression Analysis}

This study conducted a multiple linear regression analysis to test the second hypothesis. Multiple linear regression analysis was run with purchase intention as the dependent variable and the five factors from the factor analysis as the independent variables. The second hypothesis was formulated to find out the effect of perceived value on a customer's purchase intention.

H2: Perceived value has a positive influence on a customer's purchase intention for fast-food restaurants.

As can be seen in Table 23, $12.0 \%$ of the purchase intention was explained by the perceived value factors from the regression model. Results show to be significant since the sig. level is lower than the critical alpha level of 0.05 . Thus, the second hypothesis was supported and it can be concluded that there is a positive relation between value creation from perceived value and purchase intention.

However, not all perceived value factors turned out to be significant. Table 24 shows the results of each factors related to purchase intention separately. Only monetary price $(\mathrm{p}<0.05, \beta=0.305, \mathrm{t}=3.83)$ and behavioral price $(\mathrm{p}<0.05, \beta=-0.18, \mathrm{t}=-2.37)$ turned out to be significant.

Table 23

Summary of Regression Analysis $(N=303)$

\begin{tabular}{|c|c|c|c|c|}
\hline $\mathrm{R}$ & $\mathrm{R}^{2}$ & Adjusted R & $\mathrm{F}$ & Sig. \\
\hline 0.35 & 0.12 & 0.11 & 8.08 & $0.00 *$ \\
\hline
\end{tabular}


Table 24

Significance of Regression Coefficients $(N=303)$

\begin{tabular}{|c|c|c|c|c|c|c|}
\hline \multirow[b]{2}{*}{ Model } & \multicolumn{2}{|c|}{$\begin{array}{l}\text { Unstandardized } \\
\text { Coefficients }\end{array}$} & \multirow{2}{*}{$\begin{array}{c}\begin{array}{r}\text { Standardized } \\
\text { Coefficients }\end{array} \\
\text { Beta } \\
\end{array}$} & \multirow[b]{2}{*}{$\mathrm{t}$} & \multirow[b]{2}{*}{ Sig. } & \multirow{2}{*}{$\begin{array}{c}\begin{array}{c}\text { Collinearity } \\
\text { Statistics }\end{array} \\
\text { VIF }\end{array}$} \\
\hline & B & Std. Error & & & & \\
\hline 1 (Constant) & $-7.13 \mathrm{E}-16$ & 0.05 & & 0.00 & 1.00 & \\
\hline $\begin{array}{l}\text { Emotional } \\
\text { Response }\end{array}$ & 0.15 & 0.09 & 0.15 & 1.75 & 0.08 & 2.58 \\
\hline Monetary Price & 0.31 & 0.08 & 0.31 & 3.83 & $0.00 *$ & 2.14 \\
\hline Behavioral Price & -0.18 & 0.08 & -0.18 & -2.33 & $0.02 *$ & 2.08 \\
\hline Reputation & 0.03 & 0.07 & 0.03 & 0.43 & 0.67 & 1.58 \\
\hline Quality & 0.01 & 0.08 & 0.01 & 0.06 & 0.96 & 2.39 \\
\hline
\end{tabular}

Note. ${ }^{*} \mathrm{p}<0.05$.

\section{Summary}

Results indicated that Starbucks ranked as the best perceived value brand and there were significant differences in perceived value for different fast-food restaurant brands. Also, monetary and behavioral price significantly affects consumers' purchase intention. On the other hand, there was no significant relationship between purchase intention and quality, emotional response, and reputation. 


\section{CHAPTER V \\ DISCUSSION}

\section{Introduction}

This chapter includes discussions about the findings of this study and managerial implications of the findings. Also, the chapter concludes with limitations and recommendations for future research.

\section{Discussion of Results}

This study attempted to compare the perceived value of fast-food restaurant brands and find out which brand is ranked the highest. Additionally this study attempted to test the hypotheses whether perceived value differ among different fast-food restaurants brands or whether perceived value impacts purchase intention. Empirical results from this study provide valuable findings for perceived value and purchase intention for the hospitality industry. This study not only adds to the underdeveloped research stream involving perceived value in the fast-food restaurant industry, but also highlights the need to distinguish fast-food restaurants, rather than looking at them as an undifferentiated segment.

Generally, Starbucks ranked as the best perceived value brand. It turned out to be the leader in terms of quality, emotional response, and reputation. However, overall price, both monetary and behavioral of Starbucks was ranked in the bottom indicating its price was rather expensive. Next, Subway turned out to be the second leader. Subway ranked number 1 for monetary price and second for all the other perceived value dimensions. The third runner up turned out to be Wendy's. Wendy's ranked third place for all the 
perceived value dimensions except for behavioral price (ranked fourth for behavioral price).

McDonald's ranked as the fourth in total, but its behavioral price dimension was ranked the highest. Burger King ranked fifth, and Taco Bell ranked lowest in terms of its total perceived service value dimensions. Taco Bell showed the lowest ranking levels in all dimensions except for monetary price. Although the actual monetary price was not higher than the other brands, it was perceived fifth among the other brands.

The result supported two hypotheses that were generated in this study. The first hypothesis was related with examining if perceived value differ significantly among different fast-food restaurant brands. The results for this hypothesis showed that there were significant differences in perceived value for different fast-food restaurant brands. In summary, while perceived value for quality was different among most of the brands, there was no difference between McDonald's and Burger King. Starbucks, Subway, and Wendy's have a relatively higher perceived value of quality. McDonald's and Burger King were perceived pretty much the same and Taco Bell was perceived to have the lowest quality.

In terms of emotional response, significant differences were found across all brands except between Burger King and Wendy's, McDonald's, and Taco Bell; and McDonald's and Taco Bell. The results demonstrated that Starbucks and Subway are more likely than any other fast-food restaurant to be emotionally valuable. Burger King and other three restaurants (Wendy's, McDonald's, and Taco Bell) are virtually the same for emotional response, which means they share similar value characteristics. 
McDonald's and Taco Bell were perceived in the same degree and they are less likely than any other fast-food restaurants to be perceived as emotionally valuable by customers.

With regards to monetary price, Subway, McDonald's, and Wendy's have a relatively higher perceived value and significant differences were not found among them. There were significant differences between Starbucks and four other fast-food restaurants (Burger King, Wendy's, McDonald's and Subway), with Starbucks being less valued. Regarding behavioral price, statistically significant differences were found between all brands except for Subway and Starbucks, Wendy's, and Burger King; and Starbucks and Wendy's, Burger King; and Wendy's and Burger King. McDonald's has the highest perceived value and significant differentiations were not found between McDonald's and other restaurants. This result demonstrates that McDonald's distinctly differentiated behavioral price from other fast-food restaurants.

Lastly in regards to reputation, while perceived value was significantly different among most of the brands, there was no difference between McDonald's and Burger King. Starbucks, Subway, and Wendy's have a relatively higher perceived value of reputation. McDonald's and Burger King were perceived pretty much the same and Taco Bell is less likely than any other fast-food restaurant to be perceived as reputable by customers.

The second hypothesis was concerned with determining whether perceived value significantly affects a consumer's purchase intention. The results for this hypothesis indicated that such perceived value dimensions do have a positive relation with a customer's purchase intention, but not all dimensions are crucial the same extent. Perceived value dimensions of monetary price and behavioral price turns out that they 
affect the consumer's purchase intention significantly. However, there was no significant relationship between purchase intention and quality, emotional response, and reputation.

In conclusion, perceived value has a positive effect on a customer's purchase intention and it can be a competitive source to increase their intention which could eventually bring growth to fast-food restaurants. However, unlike previous studies from other hospitality industries, such as cruise, and festivals, not all five dimensions played a significant role. Thus, perceived value dimensions other than monetary price and behavioral price needs to be carefully investigated and implemented in the fast-food restaurant industry. Furthermore, perceived value dimensions may not apply by themselves to impact purchase intention. Therefore, it should not be the only source. The results of this study indicate that perceived value factors are only one element in influencing a customer's perceived value.

\section{Implications for Management}

The findings of this study have practical implications that would be able to assist management for the fast-food restaurant businesses. Consequently, all the dimensions of perceived value significantly differentiate fast-food restaurants. In particular, while Starbucks did not rank as highly in terms of monetary price and behavioral price, it was still perceived as the overall leader among the fast-food brands. Starbucks possess unique and competitive advantages as it was perceived to be the most valuable in terms of quality, emotional response, and reputation. In general, fast-food restaurants do not necessarily need to earn high perceived value in every aspect. Thus, a fast-food restaurant can earn stronger perceived values by positioning themselves by highlighting their core strengths. 
Additionally, the results showed no support for a significant difference in all dimensions of perceived value between Burger King and McDonald's except for behavioral price. Burger King and McDonald's share similar perceived value characteristics, which means they are not perceived distinctly by customers. Burger King needs to consider strategic approaches to differentiate itself from McDonalds. Generally, most of the dimensions of perceived value (quality, emotional response, behavioral price, and reputation) of Taco Bell were perceived to be the lowest by customers. Taco Bell has to improve overall perceived value in order to survive in strong competition.

This study allows a fast-food restaurant marketer to identify the key perceived value factors that increase a customer's purchase intention. It was revealed that high overall perceived value does not always mean a high purchase intention for consumers. For example, results indicate that Starbucks turns out to be the leader with respect to its overall perceived value. However, it is intriguing to note that despite the high overall perceived value, Starbucks placed the last and the second to last in terms of monetary and behavioral price as their price is comparatively more expensive. In contrast, study results indicated only monetary price and behavioral price influence a customer's purchase intention. Thus, actual sales are not necessary to be the highest although Starbucks had the highest overall perceived value. That is perhaps one reason why among all the fastfood restaurants in the USA, McDonald's came in at No. 1 in sales in 2013 although its perceived value of quality, emotional response, and reputation ranked relatively low.

Therefore, fast-food restaurants should examine each dimensions of perceived value in detail rather than merely looking at the overall perceived value. By focusing on those factors, a fast-food marketer can establish practical strategies related to purchase 
intention that can also increase sales. While, quality, emotional response, and reputation may be an important factor, fast-food restaurants should particularly focus on price compared to other aspects. Monetary price is even more critical to increase a customer's purchase intention than behavioral price. Consumers dine at fast-food restaurants not only for the quickness and consistency, but also for the price. Fast-food restaurant brands need to recognize the fact that improving the perceived value of monetary and behavioral price, is what ultimately leads to optimal profit.

For example, many businesses are engaging in social media to promote their brands and engage with their customers. It has been found that customer relationship management via social media is very powerful and effective. Nevertheless, instead of proactively just engaging in social media to earn good reputation, fast-food restaurants can develop mobile applications that can allow customers to easily order and purchase products. Adding more drive thru areas can allow customers to easily purchase their products, and creating an option to customize their combination meals may also appear to be a good bargain for customers.

Consequently, this study provides insight into the lesser known areas of the drivers of purchase intention in the hospitality context, and it suggests ways to better strategically manage perceived value for fast-food restaurants. It is crucial for fast-food restaurant marketers to understand the perceived value of their brand and find ways to effectively utilize the dimensions into their marketing strategies.

Nevertheless, fast-food restaurants can increase their perceived value and differentiate themselves among their competitors through other perceived value dimensions such as emotional response, reputation, and quality. Due to increased 
competition and changes of life style, fast-food restaurants have been struggling in business and have been trying to attempt various strategies to survive. After being competitive with monetary price and behavioral price, fast-food restaurants can stand out among their rivals and obtain more long-term sustainable competitive advantages by developing unique perceived values, as demanded by customers.

\section{Limitations}

As with all research, this study has several limitations. First of all, the data was collected only in South Florida so it might not be appropriate to generalize the findings. South Florida has distinct demographic features because it and South America are geographically close, which may have affected the quality of data gathered. Also, since more than half the participants of this study were students, it might be a limitation to generalize the results. Furthermore, the questionnaire used to collect data had fairly numerous questions (159 items), which may have influenced the response rate and the quality of data gathered.

Since this study was conducted in fast-food restaurant settings, the results of this study would not be generalizable to other types of restaurants such as the luxury and upscale segment. Also, since the results of this study are limited to the six fast-food restaurants, it is hard to apply it to new a type of fast-food restaurant such as Chipotle or Evos.

Even though it can be assumed from the results of this study that there is a positive relation between perceived value and a customer's purchase intention, $\mathrm{R}$ square value of the multiple linear regression performance indicated a low proportion of variation that was explained by the model. The R square of the correlation coefficient 
designates the proportion of the variability of the dependent variable that is explained by the regression model (Norusis, 2004). Therefore, a higher value of R square is actually preferable in terms of explaining variability. The result of the $\mathrm{R}$ square value of each multiple linear regression performance was 0.12 , indicating only $12.0 \%$ of the variability in observed perceived value dimensions were explained by purchase intention. There should be more factors that can be explained by a customer's purchase intention. Thus, it could be proposed that customers possibly find other factors more crucial than the suggested perceived value dimensions.

\section{Recommendations for Future Research}

As this is the first empirical study that had attempted to identify differences among major fast-food restaurant franchises and to find out factors that will affect a customer's purchase intention toward the restaurants, replication of this study would be important and essential to the research stream. For these reasons, this study suggests several avenues for better future study.

First of all, repeating this study with a bigger sample including various age ranges would be support in increasing generalizability of the result. Also, the application of findings of this research is limited to this particular place where the survey conducted because South Florida has unique characteristics in terms of race. Therefore, the findings of this study may not be able to generalize other regions. More empirical research is necessary for the results to be applied in other areas.

Moreover, this study was conducted only among six fast-food restaurant franchises. It did not cover new types of fast-food restaurant such as Chipotle and different types of restaurant such as luxury and upscale segment. In order to provide more 
comprehensive information and insights to a hospitality marketer, the future research needs to conduct a representative sampling to include different types of restaurants.

As a final point, other factors not used in this research may also influence a customer's purchase intention. In this study, only five dimensions of perceived value were utilized. Future study could incorporate additional variables such as satisfaction, brand image or, trust. There are more items that can be regarded as forming purchase intention as well. Also, there are more attributes that can measure purchase intention. In this study, only three predictors of purchase intention were examined. Further study should include other attributes not chosen in this study.

\section{Summary}

Consequently, the study hypotheses for this study were supported. However, only monetary and behavioral price turned out to have a positive impact on customers' purchase intention for fast-food restaurants. Practical implications were suggested to marketers. Results of this study cannot be generalized. Replication of this study with a random sample and a bigger sample size is recommended. Future studies should also include other factors that may impact purchase intention. 


\section{REFERENCES}

Ajzen, I., \& Fishbein, M. (1980). Understanding attitudes and predicting social behaviour.

Alon, I., \& McKee, D. (1999). Towards a macro environmental model of international franchising. Multinational Business Review, 7(1), 76.

Anderson, J. C., \& Narus, J. A. (1990). A model of distributor firm and manufacturer firm working partnerships. The Journal of Marketing, 42-58.

Anderson, R.E., \& Srinivasan, S.S. (2003). e-Satisfaction and e-loyalty: A contingency framework. Psychology \& Marketing, 20(2), 123-138.

Anthony, P. (2008). Encyclopedia of Global Industries, 1-16.

Armstrong, G., \& Kotler, P. (2003). Marketing: An introduction. Upper Saddle River, NJ: Prentice Hall.

Babin, B. J., Darden, W. R., \& Griffin, M. (1994). Work and/or fun: measuring hedonic and utilitarian shopping value. Journal of consumer research, 644-656.

Band WA (1991) Creating Value for Customer. New York: John Wiley.

Bolton, R. N., \& Lemon, K. N. (1999). A dynamic model of customers' usage of services: Usage as an antecedent and consequence of satisfaction. Journal of Marketing Research, 36(2), 171-186.

Burger King. (2014). International Locations. Retrieved from http://www.bk.com/international

Bussing-Burks, M. (2009). Starbucks. Santa Barbara, Calif: Greenwood Press.

Carlino, B. (1996, 19 August). BK co-founder McLamore dead at 70. Nation's Restaurant News. Retrieved from http://business.highbeam.com/409700/article-1G118609870/bk-cofounder-mclamore-dead-70

Carlino, B. (1996, August 19). BK co-founder McLamore dead at 70. Nation's Restaurant News (Subscription required).

Carlino, Bill (19 August 1996). "BK co-founder McLamore dead at 70". Nation's Restaurant News. Retrieved 25 January 2010.

Cengiz, E and Kirkbir, F (2007) Customer perceived value: the development of a multiple item scale in hospitals. Problems and Perspectives in Management, 5(3), 252-286. 
Chandon, P., Morwitz, V. G., \& Reinartz, W. J. (2005). Do intentions really predict behavior? Self-generated validity effects in survey research. Journal of Marketing, 69(2), 1-14.

Chen, Z., \& Dubinsky, A.J. (2003). A conceptual model of perceived customer value in ecommerce: A preliminary investigation. Psychology \& Marketing, 20(4), 323347.

Coelho, A. M. (2006). Franchises and franchising. Encyclopedia of American Urban Congress, Washington, DC.

Comrey, A. L., \& Lee, H. B. (1992). A first course in factor analysis. Lawrence Erlbaum Associates. Hillsdale, NJ.

Cornwell, T.B., \& Coote, L.V. (2005). Corporate sponsorship of a cause: The role of identification in purchase intent. Journal of Business Research, 58, 286-276.

Cronin, J.J., Brady, M.K., \& Hult, G.T. (2000). Assessing the effects of quality, value, and customer satisfaction on consumer behavioural intentions in service environments. Journal of Retailing, 76(2), 193-218.

DailyMail. (2014, May 1). Average American spends $\$ 1,200$ a year on fast food - that's burgers and fried chicken twice every week. Retrieved from http://www.dailymail.co.uk/news/article-2617493/Average-American-spends1-200-year-fast-food.html

Day, G.S. (1990) Market Driven Strategy: Processes for Creating Value. New York: The Free Press.

De Ruyter, K., Wetzels, M., Lemmink, J., \& Mattson, J. (1997). The dynamics of the service delivery process: a value-based approach. International journal of research in marketing, 14(3), 231-243.

Dholakia, Utpal M. and Vicki G. Morwitz (2002), "The Scope and Persistence of MereMeasurement Effects: Evidence from a Field Study of Customer Satisfaction Measurement," Journal of Consumer Research, 29 (2), 159-67.

Dodds, W.B., Monroe, K.B., \& Grewal, D. (1991). Effect of price, brand and store information on buyers' product evaluation. Journal of Marketing Research, 28(3), 307-319

Doyle, P . ( 1998 ) Marketing Management and Strategy, 2nd edn. Great Britain: Prentice Hall Europe .

Duckett, B. (2008). Business format franchising A strategic option for business growth at home and abroad. Strategic Direction, 24(2), 3-4 
Eggert, A., \& Ulaga, W. (2002). Customer perceived value: a substitute for satisfaction in business markets?. Journal of Business \& industrial marketing, 17(2/3), 107118.

Entrepreneur Magazine (2014). Fastest Growing Franchise Ranking. Retrieved from http:/www.entrepreneur.com/franchises/rankings/fastestgrowing115162/2014,-1.html

Farrell, F.P. (2008, April 25). The Evolution of the Quick Service Restaurant. Retrieved from http://jpfarrell.blogspot.com/2008/02/design-is-destiny.html.

Fishbein, M., \& Ajzen, I. (1975). Belief, attitude, intention, and behavior: An introduction to theory and research. Reading, MA: Addison-Wesley.

Franchise Help. (2015). Fast Food Industry Analysis 2015. Retrieved from https://www.franchisehelp.com/industry-reports/fast-food-industry-report/

Gale, B. T. (1994). Managing customer value (Vol. 29). New York: The Free Press.

Gallarza MG and Saura IG (2006) Value dimensions, perceived value, satisfaction and loyalty: an investigation of university students' travel behavior. Tourism Management, 27, 437-452.

Gassenheimer, J. B., Houston, F. S., \& Davis, J. C. (1998). The role of economic value, social value, and perceptions of fairness in interorganizational relationship retention decisions. Journal of the Academy of Marketing Science, 26(4), 322337.

Grewal, Dhruv., Monroe, Kent B., \& Krishnan, R. Monroe.. (1998). The Effect of PriceComparison Advertising on Buyers' Perception of Acquisition Value, Transaction Value, and Behavioral Intentions. Journal of Marketing, 62(April), 46-59.

Gronroos, C. (1997). Value-driven relational marketing: from products to resources and competencies. Journal of marketing management, 13(5), 407-419.

Groth, J. C. (1995). Exclusive value and the pricing of services. Management Decision, 33(8), 22-29.

Groth, J. C. (2001). Perceived value and psychological thresholds: implications for marketing. Marketing Intelligence \& Planning, 19(3), 145-152.

Hair, Joseph F. Jr., Black, William C., Babin, Barry J., and Anderson, Rolph E. (2010). Multivariate Data Analysis, ISBN-10, Prentice Hall, Pearson International Edition, pp 16-24, 6th-7th Edition. 
Havlena, W.J., Holbrook, M.B., (1986), The varieties of consumption experience: comparing two typologies of emotion in consumer behavior, Journai of consumer research, 13(3), 394-404.

Hellier, P. K., Geursen, G. M., Carr, R. A., \& Rickard, J. A. (2003). Customer repurchase intention: A general structural equation model. European journal of marketing, 37(11/12), 1762-1800.

Hornsby, G. D. (2011). Consistency between Franchised and Company-Owned Locations: A Study of Sonic Drive-In Food Safety Scores in the State of Oklahoma

Huber, F., Hermann, A., \& Morgan, R.E. (2001). Gaining competitive advantage through customer value oriented management. Journal of Consumer Marketing, 18(1), $41-53$.

Jacoby, J., \& Olson, J. C. (1977). Consumer response to price: an attitudinal, information processing perspective. Moving ahead with attitude research, 39(1), 73-97.

Jakle, J (1999). Fast Food: Roadside Restaurants in the Automobile Age. Johns Hopkins University Press. ISBN 080186920X.

Jargon, J. (2011, March 8). Subway Runs Past McDonald's Chain. Retrieved from http://www.wsj.com/articles/SB10001424052748703386704576186432177464 052

Jayanti, R. K., \& Ghosh, A. K. (1996). Service value determination: An integrative perspective. Journal of Hospitality \& Leisure Marketing, 3(4), 5-25.

Kantamneni, S. P., \& Coulson, K. R. (1996). Measuring perceived value: findings from preliminary research. Journal of Marketing Management, 6(2), 72-86.

Kapil, K. (2009). Retail franchising. Vision, 13(2), 81-83.

Kauffman, B. L. (2013). Seattle's Seafaring Siren: A Cultural Approach to the Branding of Starbucks (Doctoral dissertation, LIBERTY UNIVERSITY).

Khan, M. A. (2005). Internationalization of services: The global impact of U.S. franchise

Kim, A. J., \& Ko, E. (2010). Impacts of luxury fashion brand's social media marketing on customer relationship and purchase intention. Journal of Global Fashion Marketing, 1(3), 164-171.

Kim, H. \& Lee H. (2009). The effect of well-being, consumer value orientations, perceived value and brand preference on purchase intention of environmentfriendly cosmetics. J Korean Soc Clothing Ind, 15(1), 327-48 
Kim, J., Kim, J. E., \& Johnson, K. K. (2010). The customer-salesperson relationship and sales effectiveness in luxury fashion stores: The role of self monitoring. Journal of Global Fashion Marketing, 1(4), 230-239.

Kim, W. G., Ma, X., \& Kim, D. J. (2006). Determinants of Chinese hotel customers' esatisfaction and purchase intentions. Tourism Management, 27, 890-900.

Kim, W. G., Ma, X., \& Kim, D. J. (2006). Determinants of Chinese hotel customers'e satisfaction and purchase intentions. Tourism Management, 27(5), 890-900.

Kim, W., Han, H., 2008. Determinants of restaurant customers' loyalty intentions: a mediating effect of relationship quality. Journal of Quality Assurance in Hospitality and Tourism, 9(3), 218-238.

Kostecka, A. (1987). Franchising in the Economy, 1985-1987. US Department of Commerce (Washington, DC: US Government Printing Office).

Kotelikov, V. (2008). Customer retention: driving profits through giving lots of reasons to stay.

Lapierre, J. (2000). Customer-perceived value in industrial contexts. Journal of Business \& Industrial Marketing, 15(2/3), 122-145.

Lee, S. (2005). A conceptual Model of the Roles of Price, Quality, and intermediary Constructs in Determining Behavioral Intention to Visit a Festival, Texas A\&M University: College Station, Texas.

Levenstein, H. A. (2003). Paradox of plenty: A social history of eating in modern America (Vol. 8). Univ of California Press.

Lisa Magloff.(October 18, 2012). Advantages \& Disadvantages of Co-Branding Among Franchises. Chron. Retrieved from smallbusiness.chron.com.

Lloyd, A. E., \& Luk, S. T. (2010). The Devil Wears Prada or Zara: A Revelation into Customer Perceived Value of Luxury and Mass Fashion Brands. Journal of Global Fashion Marketing, 1(3), 129-141.

Lovelock, C. H. (1983). Classifying services to gain strategic marketing insights. The Journal of Marketing, 9-20.

Lovelock, C., \& Wright, L. (2002). Principles of marketing and management. ISBN 013-040467-5, Harlow/UK: Prentice Hall.

Manski, C.F. (1990). The use of intentions data to predict behavior: A best-case analysis. Journal of the American Statistical Association, 85 (412), 934-940. 
McDonald's. (2014). McDonald's History. Retrieved from http://www.aboutmedonalds.com/mcd/our_company/medonalds history timeli ne.html

McDonald's. (2014). Our Company. Retrieved from http://www.aboutmedonalds.com/med/our_company.html

McDougall. G.H.G., Levesque, T., (2000), Customer satisfaction with services: putting perceived value into equation. Journal of services marketing, 14(5), 392-10.

Mihrete, K. (2012). Association Between Fast Food Consumption and Obesity and High Blood Pressure Among Office Workers (Doctoral dissertation, Walden University).

Mittal, Vikas and Wagner A. Kamakura (2001), "Satisfaction, Repurchase Intent, and Repurchase Behavior: Investigating the Moderating Effect of Customer Characteristics," Journal of Marketing Research, 38 (1), 131-42.

Monroe, K. B. (1990). Pricing: Making profitable decisions (2nd ed., p. 52945454). New York: McGraw-Hill

Morrison, D. G. (1979). Purchase intentions and purchase behavior. The Journal of Marketing, 65-74.

Morwitz, V. G. (2001). Methods for forecasting from intentions data. In Principles of forecasting (pp. 33-56). Springer US.

Morwitz, V. G., \& Schmittlein, D. (1992). Using segmentation to improve sales forecasts based on purchase intent: Which "intenders" actually buy? Journal of Marketing Research, 29(4), 391-405.

Morwitz, Vicki G. and Gavan J. Fitzsimons (2004), “The Mere Measurement Effect: Why Does Measuring Intentions Change Actual Behavior?" Journal of Consumer Psychology, 14 (1\&2), 64-74.

National Restaurant Association. (2006). 2006/2007 restaurant industry operations report. Washington, DC: National Restaurant Association \& Deloitte and Touche, LLP.

Naumann, E. (1995). Creating customer value: the path to sustainable competitive advantage (p. 140). Cincinnati, OH: Thomson Executive Press.

Nessel, J. (2010), “10 restaurant financial red flags”, Restaurant Resource Group (RRG), available at: http://rrgconsulting.com/ten_restaurant_financial_red_flags.htm (accessed January 7, 2010).

Ngoc, N. Y. (2009). A chain from firms, green purchasing to consumers, purchase intention: A study of firms in Taiwan. Unpublished master's thesis, National 
Cheng Kung University, Tainan, The Republic of China (R.O.C). Retrieved from http://ndltd.ncl.edu.tw/cgibin/gs32/gsweb.cgi/ccd=ydI71G/webmge?Geticket=1

Novak, T.P., Donna, L.H., \& Duhachek, A. (2003). The influence of goal-directed and experiential activities on online flow experiences. Journal of Consumer Psychology, 13(1), 3-16.

Nunnally, J. (1978). C.(1978). Psychometric theory.

O'Reilly, N., Lyberger, M., McCarthy, L., Séguin, B., \& Nadeau, J. (2008). Mega-specialevent promotions and intent to purchase: a longitudinal analysis of the super bowl. Journal of Sport Management, 22(4), 392-409.

Oh, H., 2000. The effect of brand class, brand awareness, and price on customer value and behavioral intentions. Journal of Hospitality and Tourism Research, 24(2), 136-162.

Oh, L. B., \& Xu, H. (2003). Effects of multimedia on mobile consumer behavior: An empirical study of location-aware advertising. ICIS 2003 Proceedings, 56.

Olshavsky, R. W. (1985). Perceived quality in consumer decision making: an integrated theoretical perspective. Perceived quality, 3-29.

Palmer, A., \& Ponsonby, S. (2002). The social construction of new marketing paradigms: the influence of personal perspective. Journal of Marketing Management, 18(1-2), 173-192.

Panczel, Z. T. (2010). FRANCHISING AS A MODEL IN FAST FOOD INDUSTRY. Annals of DAAAM \& Proceedings.

Parasuraman, A., \& Grewal, D. (2000). The impact of technology on the quality-valueloyalty chain: a research agenda. Journal of the academy of marketing science, 28(1), 168-174

Park, C. W., Jaworski, B. J., \& Maclnnis, D. J. (1986). Strategic brand concept-image management. The Journal of Marketing, 135-145.

Petrick, J. F. (1999). An Examination of the Relationship Between Golf Traveler's Satisfaction, Perceived Value and Loyalty and Their Intentions to Revisit. University Microfilms.

Petrick, J. F. (2002). Development of a multi-dimensional scale for measuring the perceived value of a service. Journal of Leisure Research. 34(2), 119-134.

Powers. T. (1992). Introduction to Management in the Hospitality Industry (4th ed). New York: John Wiley \& Sons. Inc. 
Pura, M. (2005). Linking perceived value and loyalty in location-based mobile services. Managing Service Quality, 15(6), 509-538.

QSR Magazine. (2014). The top 50 brands in quick service and fast casual. Retrieved August 1, 2014, from http://www.qsrmagazine.com/reports/qsr50-2014-top-50chart

Rahatullah, M., \& Raeside, R. (2009). The dynamism of partner selection criteria in franchising. SA.M Advanced Management Journal, 74(4), 36-46.

Ranganathan, C., \& Ganapathy, S. (2002). Key dimensions of business-to-consumer web sites. Information and Management, 39(6), 457-465.

Reichheld, F. P., \& Sasser, W. E. (1990). Zero defections: quality comes to services. Harvard business review, 68(5), 105-111.

Richardson, C. B. (2001). Retention of successful restaurant managers in the quick service restaurant industry (Unpublished doctoral dissertation). Benedictine University, Chicago, IL. 157

Ries, A., \& Trout, J. (2001). The Marketing Classic Positioning: how to be seen and heard in the overcrowded marketplace.

Robinson, C, Abbott, J., \& Shoemaker, S. (2005). Recreating cheers: An analysis of relationship marketing as an effective marketing technique for quick-service restaurants. International Journal of Contemporary Hospitality Management, 17(6/1), 590-599.

Samadi, N. (2010). On the fast track: Restaurants expand their menus and global operations to boost demand Fast Food Restaurants in the US About this Industry, (December), 1-38.

Sanchez, J., Callarisa L., Rodriguez M.R., Moliner A.M., (2006), Perceived value of the purchase of a tourism product. Tourism management, 2006, 394-409.

Schiffman, L. G., \& Kanuk, L. L. (2000). Consumer Behavior, 7th.

Schlosser, E. (1998). Fast Food Nation: The True Cost of America's Diet. Rolling Stone, September, 3.

Schlosser, E. (2012). Fast food nation: The dark side of the all-American meal. Houghton Mifflin Harcourt.

Schultz, H., \& Yang, D. J. (1997). Pour your heart into it: How Starbucks built a company one cup at a time. New York, NY: Hyperion. 
Sheth, J. N., Newman, B. I., \& Gross, B. L. (1991). Why we buy what we buy: a theory of consumption values. Journal of business research, 22(2), 159-170.

Smith, A. F. (2006). Encyclopedia of junk food and fast food. Greenwood Publishing Group.

Smith, A. F. (2006). Encyclopedia of junk food and fast food. Greenwood Publishing Group.

Spears, N., \& Singh, S.N. (2004). Measuring attitude toward the brand and purchase intentions. Journal of Current Issues and Research in Advertising, 26(2), 53-66.

Starbucks. (2014). Company Information. Retrieved from http:/www.starbucks.com/about-us/company-information

Statista. (2014). Revenue of the United States fast food restaurant industry from 2002 to 2018. Retrieved from http://www.statista.com/statistics/196614/revenue-ofthe-us-fast-food-restaurant-industry-since-2002/

Subway. (2014). Explore Our World. Retrieved from http://www.subway.com/subwayroot/exploreourworld.aspx

Sweeney, J. C., \& Soutar, G. N. (2001). Consumer perceived value: The development of a multiple item scale. Journal of retailing, 77(2), 203-220.

Sweeney, J. C., Soutar, G. N., \& Johnson, L. W. (1998). Consumer perceived value: Development of a multiple item scale. American Marketing Association Conference Proceedings, 9, 138.

Sweeney, J. C., Soutar, G. N., \& Johnson, L. W. (1999). The role of perceived risk in the quality-value relationship: a study in a retail environment. Journal of retailing, 75(1), 77-105.

Tabo Bell. (2015). Company Information. Retrieved from http://www.tacobell.com/Company

Tauber, E.M. (1975). Predictive validity in consumer research. Journal of Advertising Research, 15(5), 59-64.

Thang, D. D. (2008). Factors Affecting Consumers' Purchase Intention in Vietnam Helmet Market. Unpublished master's thesis, National Cheng Kung University, Tainan, The Republic of China (R.O.C). Retrieved from http://ndltd.ncl.edu.tw/cgibin/gs32/gsweb.cgi/ccd=ydI71G/webmge?Geticket=1

The Caterer. (2011). McDonald's Restaurants. Retrieved from http://www.thecaterer.com 
Toedo Blade. (1991, November 21).Taco Bell Express makes fast food look slow. Toedo Blade, p. 17.

Ulaga, W., Chacoitr S., (2001), Measuring Customer-Perceived Value in Business Markets, Industrial Marketing Management, 30, 525-540.

United States. (1990). Special Report by the Committee on Small Business, United States

Wakefield, R.J., Stocks, M.H., \& Wilder, W.M. (2004). The role of web site characteristics in initial trust formation. Journal of Computer Information Systems, 45(1), 94-103.

Ware. R., \& Rudnick. J. (1991). How to open your own restaurant: A guide for entrepreneurs. New York: Penguinbooks.

Wendy's. (2015). The Wendy’s Company. Retrieved from https://www.wendys.com/enus/about-wendys/the-wendys-company

Wendy's. (n.d.). In Wikipeida online. Retrieved from http://en.wikipedia.org/wiki/Wendy\%27s\#Menu

Wikinvest (2012). Fast Food Restaurants (QSR). http://www.wikinvest.com/industry/Fast_Retrieved from Food_Restaurants_\%28QSR\%29

Woodruff, R. B. (1997). Customer value: the next source for competitive advantage. Journal of the academy of marketing science, 25(2), 139-153.

Woodruff, R. B., \& Gardial, S. (1996). Know your customer: New approaches to understanding customer value and satisfaction. Wiley.

Xie, L., \& Chen, C. C. (2014). Hotel loyalty programs: how valuable is valuable enough?. International Journal of Contemporary Hospitality Management, 26(1), 107129.

Yang, Z., \& Peterson, R. T. (2004). Customer perceived value, satisfaction, and loyalty: The role of switching costs. Psychology \& Marketing, 21(10), 799-822.

Zeithaml, V. A. (1988). Consumer perceptions of price, quality, and value: A means-end model and synthesis of evidence. Journal of Marketing, 52(3), 2-22. 
APPENDIX: A QUESTIONNAIRE

Fast-food Restaurant Perceived Value Survey

Q1: What is your GENDER?

Male $\quad \square$ Female

Q2: What is your MARITAL STATUS?

single $\square$ married $\square$ divorced $\square$ separated $\square$ other

Q3: What is your AGE range?
$18-25$
$26-35$
$36-45$
$46-55$
$56-65$
66 and over

Q4: Please select your approximate ANNUAL FAMILY INCOME (Used for demographic purposes, only)
$\$ 39,999$ or less
$\$ 120,000-\$ 159,999$
$\square$ I respectfully decline to answer
$\$ 40,000$ - $\$ 79,999$
$\$ 160,000$ - \$199,999
$\$ 80,000-\$ 119,999$
$\$ 200,000$ and over

\section{Q5: Which BEST describes YOU?}

Caucasian (Non-Hispanic)

Hispanic

American Indian
African American/Black (Non-Hispanic)

Asian or Pacific Islander

$\square$ Mixed Race/Other

Q6: What is your HIGHEST level of EDUCATION?
High School
Associate's Degree
Bachelor's Degree
Master's Degree
Doctoral Degree
Other Education/Trade 
Q7: Please rate your level of perceived value at the following fast-food restaurants on a 5 point Likert scale shown below.

\begin{tabular}{|c|c|c|c|c|}
\hline 1 & 2 & 3 & 4 & 5 \\
\hline Very low & Low & Neutral & High & Very high \\
\hline
\end{tabular}

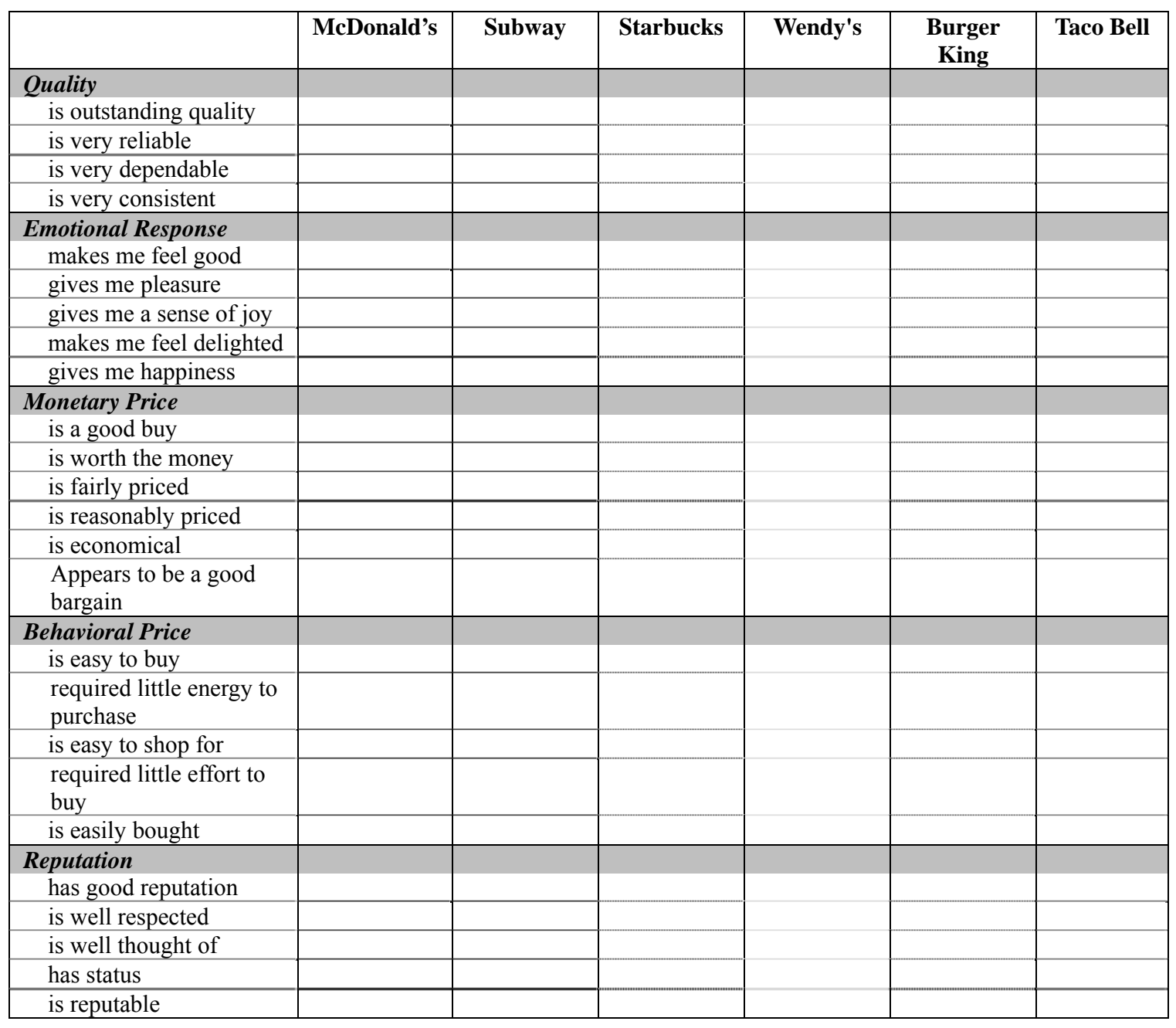

Q8. Please indicate how likely the perceived value attributes above affect your purchasing decision?

\begin{tabular}{|l|c|c|c|c|c|}
\hline & Not at all likely & \multicolumn{3}{|c|}{ Extremely likely } \\
\hline INTENTIONS & $\mathbf{1}$ & $\mathbf{2}$ & $\mathbf{3}$ & $\mathbf{4}$ & $\mathbf{5}$ \\
\hline Willing to visit the fast-food restaurant in the future. & & & & & \\
\hline Visit the fast-food restaurant. & & & & & \\
\hline Recommend the fast-food restaurant to people you know. & & & & & \\
\hline
\end{tabular}

